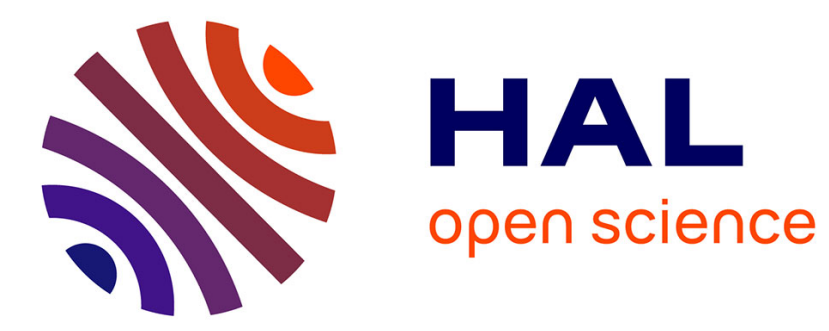

\title{
Heat transfer and air flow in a domestic refrigerator \\ Onrawee Laguerre
}

\section{To cite this version:}

Onrawee Laguerre. Heat transfer and air flow in a domestic refrigerator. Mathematical Modelling of Food Processing, Mohammed M. Farid (ed.), CRC Press, p. 445 - p. 474, 2010, Contemporary Food Engineering, 9781420053517. hal-00583230

\section{HAL Id: hal-00583230 \\ https://hal.science/hal-00583230}

Submitted on 5 Apr 2011

HAL is a multi-disciplinary open access archive for the deposit and dissemination of scientific research documents, whether they are published or not. The documents may come from teaching and research institutions in France or abroad, or from public or private research centers.
L'archive ouverte pluridisciplinaire $\mathbf{H A L}$, est destinée au dépôt et à la diffusion de documents scientifiques de niveau recherche, publiés ou non, émanant des établissements d'enseignement et de recherche français ou étrangers, des laboratoires publics ou privés. 


\title{
16 Heat Transfer and Air Flow in a Domestic Refrigerator
}

\author{
Onrawee Laguerre \\ UMR Génie Industriel Alimentaire Cemagref-ENSIA-INAPG-INRA
}

\section{CONTENTS}

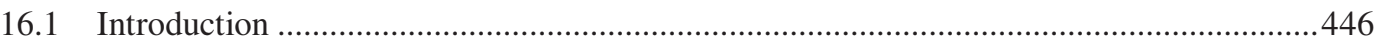

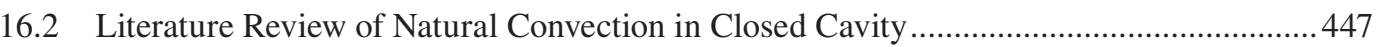

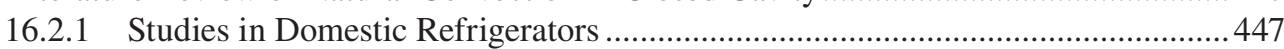

16.2.2 Heat Transfer and Airflow Near a Vertical Plate .................................................448

16.2.3 Heat Transfer and Airflow in Empty Closed Cavity............................................ 450

16.2.4 Heat Transfer and Airflow in Cavity Completely or Partially

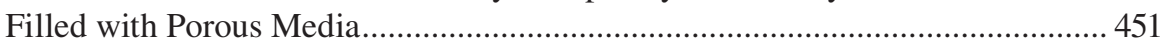

16.3 Cold Production System in Domestic Refrigerators/Freezers ............................................. 452

16.4 Temperatures and Heat Transfer Modes in Domestic Refrigerators ...................................... 453

16.4.1 Temperature in Refrigerating Compartment ...................................................... 453

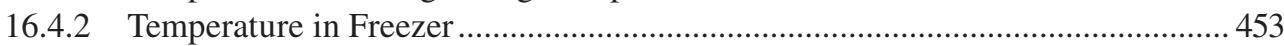

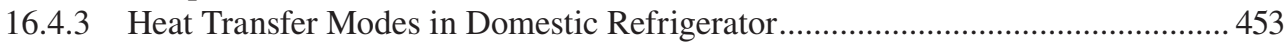

16.5 Example of Heat Transfer Analysis in a Typical Refrigerator..............................................456

16.5.1 Empty Refrigerator Considered as being a Closed Rectangular Cavity................ 456

16.5.2 Empty Refrigerator Considered as a Combination of Vertical Plates ................... 457

16.5.2.1 Estimation of the Convective Heat Transfer Coefficient by

Natural Convection between the Evaporator and Air $\left(h_{\text {evap }}\right) \ldots \ldots \ldots \ldots \ldots . . . . .457$

16.5.2.2 Estimation of the Radiative Heat Transfer Coefficient between the Evaporator and the other Walls $\left(h_{r}\right)$................................ 458

16.5.2.3 Estimation of the Convective Heat Transfer Coefficient between Air and the Internal Walls of the

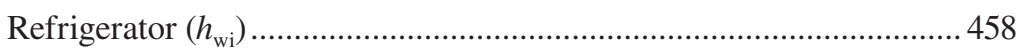

16.5.2.4 Estimation of the Overall Heat Transfer Coefficient and

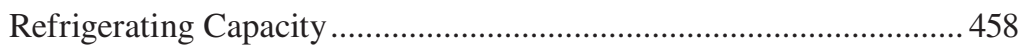

16.5.2.5 Estimation of the Thickness of the Thermal Boundary

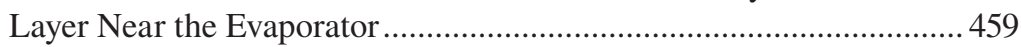

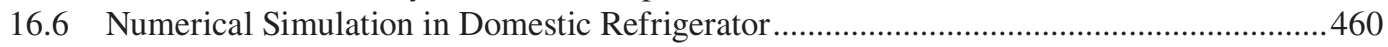

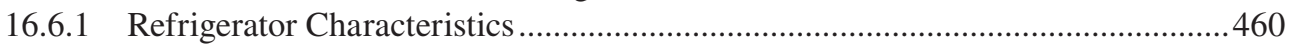

16.6.2 Measurement of the Thermal Resistance of Refrigerator Insulation.................... 461

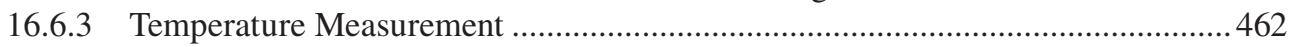

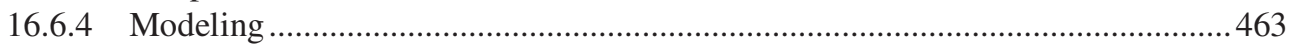

16.6.4.1 Main Assumptions and Boundary Conditions.................................... 463

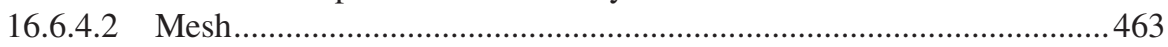

16.6.4.3 Discrete Ordinate (DO) Method for Radiation......................................463

16.6.5 Numerical Results (Taking into Account Radiation).............................................465

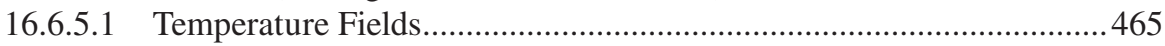


16.6.5.2 Air Velocity Field.

16.7 Conclusions

Acknowledgment .

Nomenclature

References

\subsection{INTRODUCTION}

Domestic refrigerators are widely used in industrialized countries. There are approximately 1 billion domestic refrigerators worldwide ${ }^{1}$ and the demand in 2004, was 71.44 million units (including 11.2 in China, 10.7 in the United States, 4.43 in Japan, 3.36 in India, 3.14 in Brazil ${ }^{2}$ ). In developing countries, the production is rising steadily: total production rose $30 \%$ in $2000 .{ }^{3}$ In France, there are 1.7 refrigerators per household. ${ }^{4}$

Epidemiological data from Europe, North America, Australia and New Zealand indicate that a substantial proportion of foodborne disease is attributed to improper food preparation practices in consumers' homes. ${ }^{5}$ Data also illustrate that a large proportion of consumers lack knowledge of adequate refrigeration temperatures. Surveys carried out in various countries on the temperature and the microbial contamination in the refrigerating compartment under real use conditions show an alarming situation. ${ }^{6-13}$ Compared with surveys on the refrigerating compartment, a few surveys have been carried out on temperatures in domestic freezers. ${ }^{14}$ Product temperature is a quality and safety-determining factor. It is therefore necessary to fully understand the mechanism of heat transfer and airflow.

Three types of domestic refrigerators are available in the market: static, brewed, and no-frost. The static type (Figure 16.1a) is widely used in Europe. In this case, heat is transferred principally by natural convection and airflow is due to variations in air density. These variations are related principally to the temperature and humidity gradients. The vertical force which results from air weight and buoyancy is ascendant if air is locally lighter than the average and descendant where the opposite is true (hot/humid air is lighter than cold/dry air). There is a combination of heat transfer and airflow inside refrigerators i.e., heat transfer from air to the evaporator (vertical plate), to the other walls (cavity) and to products (various forms). Due to the principal of heat transfer, temperature heterogeneity is often observed in this type of refrigerator. The position of the evaporator

(a)

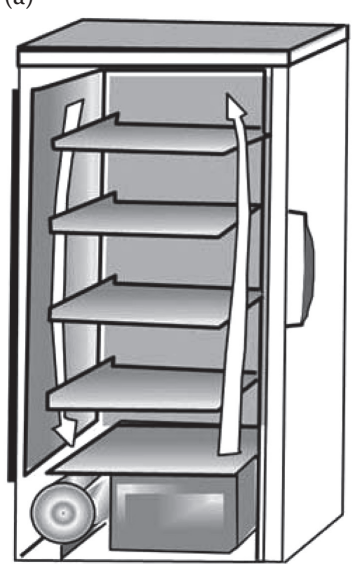

(b)

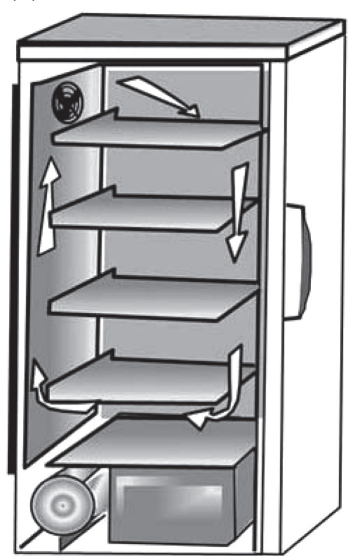

(c)

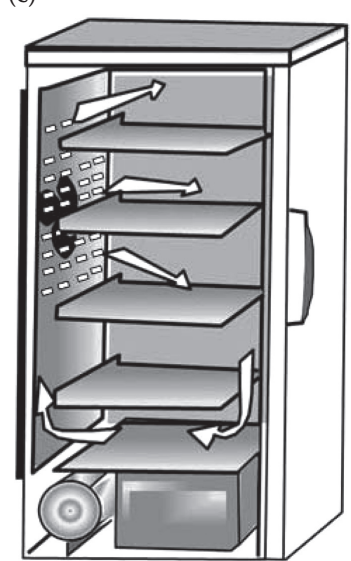

FIGURE 16.1 Three types of refrigerator: (a) static, (b) brewed, (c) no-frost. 
(horizontal/vertical, top/bottom of the compartment) determines the location of cold and warm zones. The brewed type is a static refrigerator equipped with a fan (Figure 16.1b). It allows air circulation and the temperature decreases rapidly after door opening. Air temperature is more homogeneous in this case than in the static type but the energy consumption is higher due to the fan. In a no-frost refrigerator (Figure 16.1c), a fan (embedded in the back wall) pushes air to flow over the evaporator before entering into the refrigerating compartment. Air temperature is more homogeneous compared to the two other refrigerator types. Disadvantages of no-frost type are noise, energy consumption, drying on food surface and high price.

It should be remembered that the refrigerator design in the United States and in Europe is quite different: particularly, in the United States, the size of appliances is bigger and there are more refrigerators equipped with fan.

Generally, the external dimensions of commercialized refrigerator are $60 \times 60 \mathrm{~cm}$ (width $\times$ depth) and the height varies between $90 \mathrm{~cm}$ and over $2 \mathrm{~m}$. The wall thickness is approximately $4 \mathrm{~cm}$ and the refrigerator is generally made of polystyrene (inner liner), polyurethane (insulating material) and metal sheet (outer liner).

Knowledge of air temperature and velocity profiles in a refrigerator is important for food quality control. In fact, if the consumer knows the position of warm and cold zones in the refrigerator, the product can be placed correctly. Knowledge of thermal and hydrodynamic boundary layers near the evaporator and the other walls is also important. If the product is too close to the evaporator wall, freezing can occur, and if it is too close to the other walls, there may be health risks.

The objective of this chapter is to present the state of the art of knowledge on heat transfer and airflow by natural convection in domestic refrigerators. Several subjects are dealt with: literature review of natural convection in closed cavity, cold production system of domestic refrigerators, temperatures and different heat transfer modes in appliances. Finally, an example of heat transfer analysis and numerical simulation in a typical refrigerator will be shown.

\subsection{LITERATURE REVIEW OF NATURAL CONVECTION IN CLOSED CAVITY}

A literature review on natural convection in domestic refrigerators, near a vertical plate, in empty closed cavities and in cavities filled with porous media will be presented. Some limits of the application of these studies to our case (refrigerator loaded with a food product) will also be given.

\subsubsection{Studies in Domestic Refrigerators}

Several experimental studies were carried out on empty and loaded refrigerators., ${ }^{75}$ The objective was to analyze the effects of several parameters on the temperature in the refrigerating compartment (thermostat setting, frequency of door openings, filled volume, temperature and humidity of ambient air). However, few studies were carried out on airflow measurement due to the complexity of metrology techniques compared to temperature. Airflow measurement in a freezer compartment under real operating conditions was carried out by Lacerda et al. ${ }^{16}$ using PIV (particles imagery velocimetry). It was observed that the flow field was strongly influenced by the temperature variations due to the "on" and "off" operation cycles of compressor. This behavior was attributed to natural convection and strong temperature dependency of air viscosity. Another study on airflow in a ventilated domestic freezing compartment was carried out by Lee et al. ${ }^{17}$ In this study a comparison of velocity field obtained by CFD simulation and by experiments (PIV measurements) was undertaken. These authors observed that the flow was very complex: jet-like flow around entrance ports, impinging and stagnation flow on the walls and a large recirculation flow in cavity. To our knowledge, no study was carried out on air velocity measurement in a refrigerating compartment. Moreover, airflow being strongly influenced by the aspect ratio (height/width) of the cavity; the flow in a freezer is therefore different from the one in a refrigerating compartment. 
To obtain useful information on natural convection in a domestic refrigerator, airflow in some well known configurations will be presented: near a warm (or cold) vertical plate, empty cavity and cavity filled with product. The temperature of the cold wall is constant for these three configurations in spite that this temperature fluctuates due to the "on" and "off" compressor working cycles in a real refrigerator.

\subsubsection{Heat Transfer and Airflow Near a Vertical Plate}

For a first approach, literature on flow adjacent to a cold vertical plate placed in a warm environment (without other limiting walls) can be applied for a good understanding on how airflow by natural convection nears the refrigerators evaporator. If a tracer (e.g., smoke) is injected at one end of the plate to visualize the flow, laminar flow is firstly observed near the wall and then turbulence appears (Figure 16.2). The air velocity $(u)$ is zero at the plate surface, then, it increases rapidly at locations away from the plate to attain a maximum value $\left(u_{m}\right)$. Air velocity then decreases and approaches zero, which is the velocity far from the plate (Figure 16.3). The zone of nonzero velocity $\left(u>u_{m} / 100\right)$ is called the hydrodynamic boundary layer and its thickness $(\delta)$ increases in the flow direction $(x)$.

The air temperature $(T)$ increases from the wall temperature $\left(T_{\mathrm{w}}\right)$ to the ambient temperature $\left(T_{\infty}\right)$ (Figure 16.4). The zone where the temperature differs from ambient $\left(\left(T-T_{\infty}\right)>\left(T_{\mathrm{w}}-T_{\infty}\right)\right)$ is called the thermal boundary layer and its thickness $\left(\delta_{T}\right)$ increases in the flow direction $(x)$.

The equivalent boundary thermal layer thickness $\left(\delta_{T, \mathrm{eq}}\right)$ is also frequently used in practice; it is defined as $\delta_{T, \mathrm{eq}}=\lambda / h \delta$.

When Prandtl number (Pr) is near 1 such as in the case of air, the equivalent boundary layer thickness $\left(\delta_{T, \text { eq }}\right)$ is of the same order of magnitude as that of the thermal boundary layer $\left(\delta_{T}\right)$. For example, for laminar forced convection, $\delta_{T, \mathrm{eq}}=2 / 3 \cdot \delta_{T}$.

The flow regime in natural convection is characterized by the Rayleigh number ( $\mathrm{Ra})$ defined as:

$$
\mathrm{Ra}=\frac{g \beta \Delta T L^{3}}{\alpha v}
$$

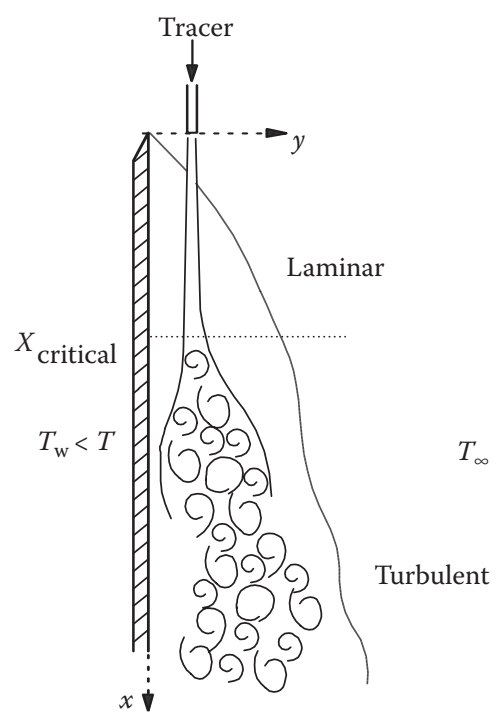

FIGURE. 16.2 Air flow by natural convection near the wall. 


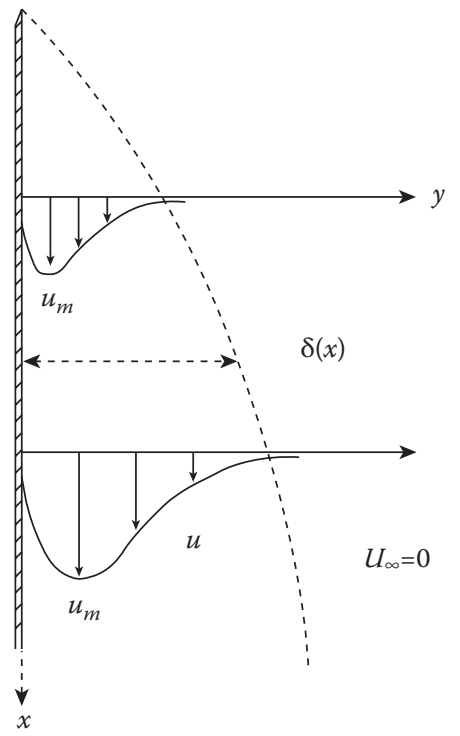

FIGURE. 16.3 Hydrodynamic boundary layer and velocity profile in natural convection flow.

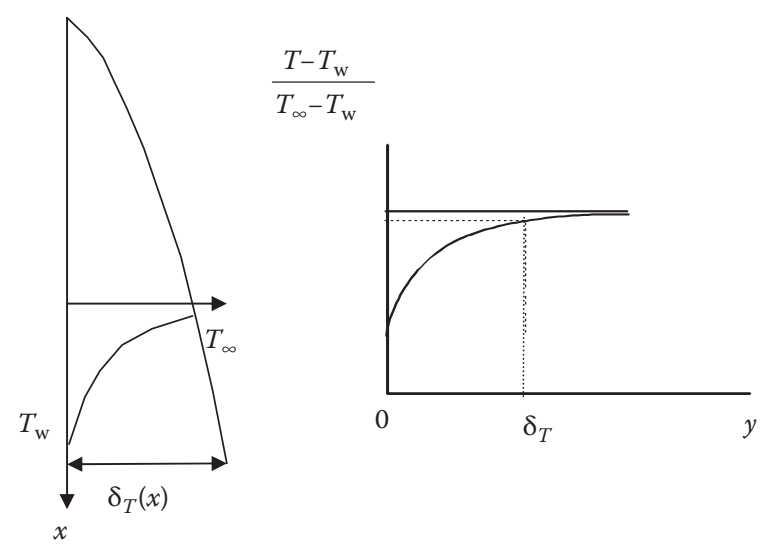

FIGURE 16.4 Thermal boundary layer, temperature profile and dimensionless profile in natural convection.

In general, the critical Rayleigh number, which distinguishes the transition from laminar to turbulent flows, is approximately $10^{9}$ (depending on the geometry and boundary conditions. ${ }^{18}$

Heat transfer phenomena depend on the flow regimes (laminar or turbulent). Khalifa ${ }^{19}$ presents a literature review of natural convection heat transfer correlations for vertical or horizontal plates. More than 40 articles are presented in this review. The experimental conditions are summarized: dimension of the tested surface, fluid type, temperature difference between the plate and the fluid, and Rayleigh number range. A strong variation in the values of heat transfer coefficient was found from using these different correlations.

In general, the correlations are presented in the following form:

$$
\mathrm{Nu}=a \cdot \mathrm{Ra}^{n}
$$


" $a$ " and " $n$ " are coefficients whose value depends on the flow regime. For example, for a vertical plate, Incropera and Dewitt ${ }^{18}$ proposed:

$a=0.59$ and $n=1 / 4$ for laminar flow,

$a=0.10$ and $n=1 / 3$ for turbulent flow.

\subsubsection{Heat Transfer and Airflow in Empty Closed Cavity}

Several experimental studies were carried out to measure air temperature and/or velocity in closed cavities. ${ }^{20-24}$ Ostrach $^{25}$, Catton ${ }^{26}$, and Yang ${ }^{27}$ carried out a literature review on this subject, which included both the experimental and modeling results (2D and 3D). These authors emphasize the importance of the aspect ratio of the cavity and the temperature difference between walls on the flow regimes.

When the bottom horizontal wall is cold, stable temperature stratification is observed in the cavity (cold zone at the bottom and warm zone at the top), and there is no airflow. When the upper horizontal wall is cold, unstable flow is observed ${ }^{25}$ due to gravity. The state of unstable equilibrium occurs until a critical density gradient is exceeded. A spontaneous flow then results that eventually becomes steady and cellular-like. When a vertical wall is cold, circular flow is observed along walls and the air is almost stagnant at the center of the cavity; thermal stratification is also observed. This case is similar to that of a domestic refrigerator, since the evaporator is often inserted in the vertical back wall.

There are fewer experimental studies on natural convection than on forced convection due to experimental difficulties in terms of metrology for low velocity and design of experimental devices maintaining given wall conditions. In fact, measurement is very sensitive to experimental and boundary conditions. Henks and Hoogendoorn ${ }^{28}$ compared some experimental results obtained with a standard case $\left(\mathrm{Ra}=5 \times 10^{10}\right.$, cavity aspect ration $H / L=1$ in $3 \mathrm{D}$, adiabatic horizontal walls). Good agreement between results was found, particularly about the temperature and velocity profiles within the boundary layers.

Ramesh and Venkateshan ${ }^{29}$ used a differential interferometer to visualize conditions in the boundary layer along the wall $\left(10^{5}<\mathrm{Ra}<10^{6}\right)$. They found that it is generally stable except in the corner. Mergui and Penot ${ }^{23}$ carried out a visualization of flow in an empty cavity using a laser tomography $\left(\mathrm{Ra}=1.7 \times 10^{9}\right)$; they observed the same phenomena as Ramesh and Venkateshan ${ }^{29}$.

Deschamps et al. ${ }^{30}$ reported that in a domestic refrigerator, the Rayleigh number varies from $10^{8}$ and $10^{9}$, and that flow is therefore, in the transition regime between laminar and turbulent flow.

Heat exchange by radiation between internal walls of the cavity is as important as that achieved with natural convection and this should be taken into account. Several authors ${ }^{31-34}$ showed by experimental and numerical approaches that these two heat transfer modes occur simultaneously. Ramesh and Venkateshan ${ }^{32}$ showed experimentally that for a square enclosure (vertical walls maintained at 35 and $65^{\circ} \mathrm{C}$, adiabatic horizontal walls, $\mathrm{Ra}=5 \times 10^{5}$ ), the heat transfer by convection and radiation between high emissive vertical walls $(\varepsilon=0.85)$ is twice of that of polished ones $(\varepsilon=0.05)$. Balaji and Venkateshan ${ }^{31}$ proposed correlations established from numerical simulations to express the convection and radiation in a square cavity as a function of $\varepsilon, \mathrm{Ra}, T_{c} / T_{h}$ and a radiation convection interaction parameter

$$
N_{\mathrm{RC}}=\frac{\sigma T_{\mathrm{wh}}^{4} H}{\lambda\left(T_{\mathrm{wh}}-T_{\mathrm{wc}}\right)} .
$$

These correlations show that the radiation effect increases when the wall emmisivity and/or wall temperatures increase. Moreover, $\mathrm{Li}$ and $\mathrm{Li}^{34}$ reported that the radiation relative to convection 
increases as the size of enclosure increases. An estimation of convection and radiation heat transfer in a refrigerator was carried out in our previous study ${ }^{35}$, which confirms the importance of radiation.

\subsubsection{Heat Transfer and Airflow in Cavity Completely or Partially Filled with Porous Media}

Several reviews on heat transfer by natural convection in a cavity filled with porous media have been carried out. ${ }^{36-39}$ In the case of porous media, the Rayleigh number is defined as:

$$
\mathrm{Ra}_{p}=\frac{g \beta \Delta T \cdot H \cdot K}{\alpha_{p} v}
$$

When Rayleigh number is less than a critical value $\left(\mathrm{Ra}_{c}\right)$, the heat transfer is dominated by conduction. When $\mathrm{Ra}_{p}>\mathrm{Ra}_{c}$, airflow is observed, which leads to a heat transfer dominated by convection. Oosthuizen ${ }^{39}$ reported a value of 40 for $^{\mathrm{Ra}_{c}}$ in a rectangular cavity heated from below.

Airflow in a cavity filled with porous media is generally laminar. Circular flow, similar to that of an empty cavity, is observed in the boundary layer along the walls (Figure 16.5). Velocity is much smaller at the center of the cavity.

Literature concerning heat transfers in porous media and in packed beds $s^{40-42}$ presents several approaches taking into account heat transfer by conduction, convection and radiation. Moreover, these studies distinguish the one-temperature models, in which local equilibrium between product and air is assumed, from the two-temperature models, in which different temperatures represent product and air statement not clear.

The literature on cavity filled with porous media cannot be applied directly to the case of loaded domestic refrigerator principally due to the large variation in products dimension. For refrigerators, the ratio between the dimension of product and cavity is about $0.10(\sim 5 \mathrm{~cm}$ product width and $\sim 50$ $\mathrm{cm}$ cavity width) while this ratio is $\leq 0.02$ for porous media. There is notably a great influence of product position on heat transfer compared to the case of porous media. This was shown in our previous studies ${ }^{43}$ that demonstrate the influence of these parameters on the heat transfer at low air velocity $(<0.2 \mathrm{~m} / \mathrm{s})$ in a stack of spheres.

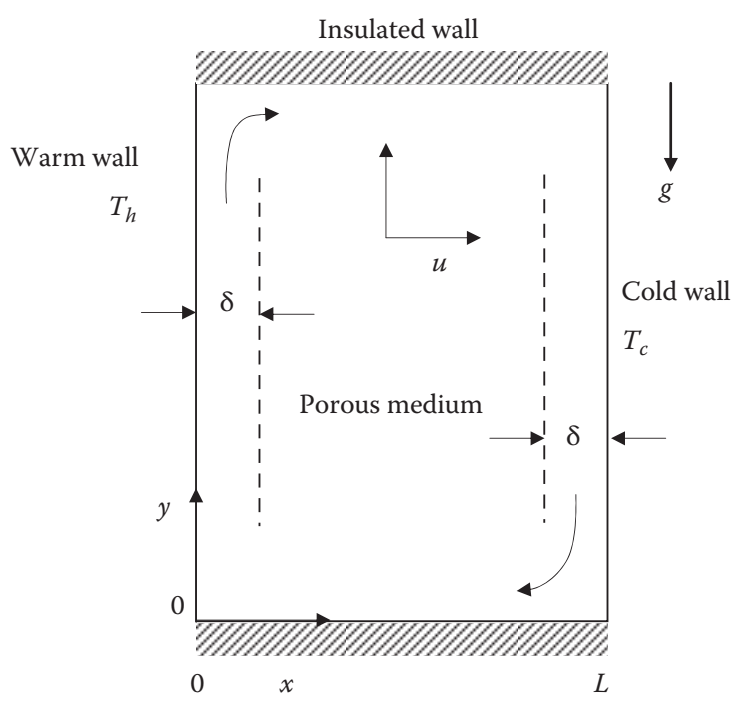

FIGURE 16.5 Two-dimensional rectangular porous layer held between differentially heated side walls. 


\subsection{COLD PRODUCTION SYSTEM IN DOMESTIC REFRIGERATORS/FREEZERS}

The most common refrigerators and freezers have four major parts in their refrigeration system-a compressor, a condenser, an expansion valve and an evaporator (Figure 16.6). In the evaporator section, a refrigerant (commonly R600a and R134; still in use R12 and ammonia) is vaporized to absorb heat added into the refrigerator due to heat transfer across the refrigerators walls and infiltration through the door and seals and during door opening. The refrigerant boils at -18 to $-20^{\circ} \mathrm{C}$ when pressurized at $0.9-1$ bar, so the evaporator temperature is maintained at or near that temperature if the appliance is working correctly. In the next stage, an electric motor runs a small piston compressor and the refrigerant is pressurized. This raises the temperature of the refrigerant and the resulting superheated, high-pressure gas (it is still a gas at this point) is then condensed to a liquid in an aircooled condenser. In most refrigerators and freezers, the compressor is in the base and the condenser coils are at the rear of the appliance. From the condenser, the liquid refrigerant flows through an expansion valve (almost always a capillary tube), in which its pressure and temperature are reduced and these conditions are maintained in the evaporator. The whole process operates continuously, by transferring heat from the evaporator section (inside the refrigerator) to the condenser section (outside the refrigerator), by pumping refrigerant continuously through the system described above. When the desired temperature is reached, the pump stops and so does heat transfer.

The refrigerator/freezers may be equipped with one or two compressors. In the case of one compressor, the operating cycle is both controlled by the air temperature in the refrigerating compartment and in freezer. In the case of two compressors, each operating cycle is independently controlled

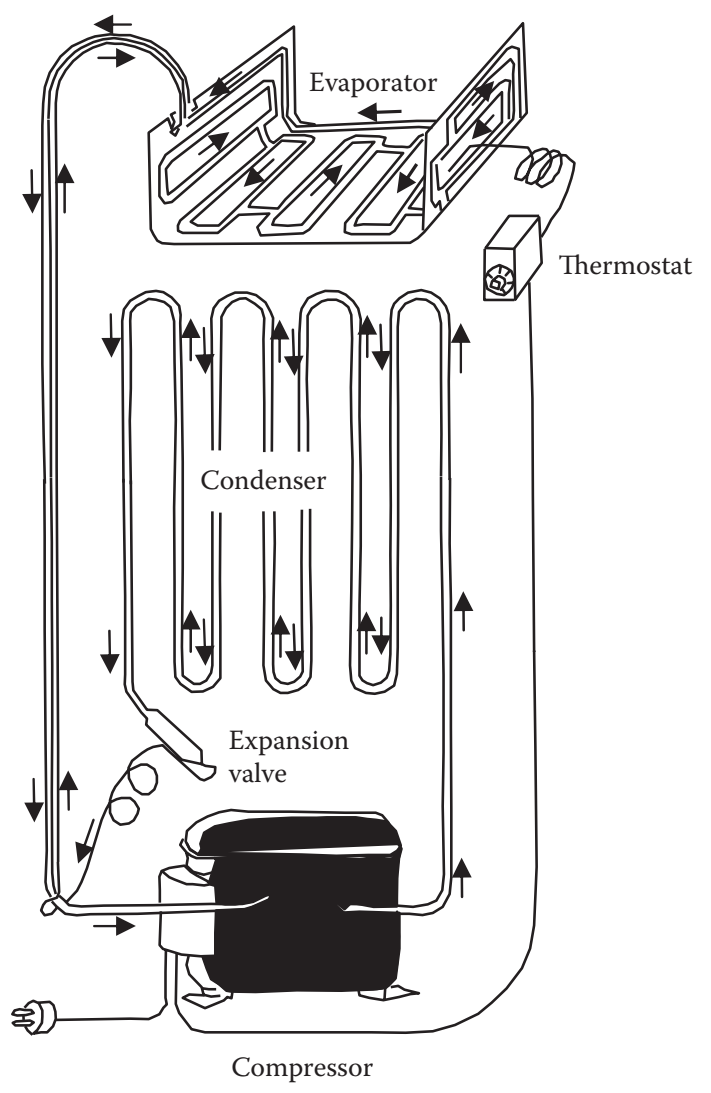

FIGURE 16.6 Cold production system in a domestic refrigerator/freezer. 
by the air temperature in the refrigerating compartment and in the freezer. The temperature in each compartment is, therefore, better regulated but the price is higher.

\subsection{TEMPERATURES AND HEAT TRANSFER MODES IN DOMESTIC REFRIGERATORS}

The "on" and "off" operating cycle of the compressor leads to temperatures fluctuations in the refrigerator. The air temperature inside the appliance is regulated by a thermostat. When this temperature, measured at a given position, is higher than the maximum setting value, the compressor is "on" until the minimum setting value is reached, and then it is switched "off." The difference between maximum and minimum settings is fixed by the manufacturer.

\subsubsection{Temperature in Refrigerating Compartment}

The temperatures in a refrigerating compartment of an empty one-door refrigerator equipped with one compressor, measured using calibrated T-type thermocouples are presented here. The internal dimensions of this compartment were $50 \times 50 \mathrm{~cm}$ (width $\times$ depth) and the height was $90 \mathrm{~cm}$. The vertical walls exchanged heat with the external ambience. The thickness of these walls was $4 \mathrm{~cm}$ and the overall thermal conductivity was $0.027 \mathrm{~W} /\left(\mathrm{m}^{\circ} \mathrm{C}\right)$. The evaporator was fitted inside the vertical back wall and it was $50 \mathrm{~cm}$ wide and $30 \mathrm{~cm}$ high.

The temperature variations are shown in Figure 16.7 for a thermostat setting at $6^{\circ} \mathrm{C}$ and the average ambient temperature at $20^{\circ} \mathrm{C}$. The "on" and "off" compressor work cycles lead to variations in the evaporator wall temperature ( $T_{\text {evap }}$ ) (Figure 16.7a). It can be seen that the temperature varies within a range of $+7^{\circ} \mathrm{C}$ to $-12^{\circ} \mathrm{C}$ (average temperature $-1.2^{\circ} \mathrm{C}$ ).

The air temperature was measured at the top, middle, and bottom levels at the center of the refrigerating compartment (Figure 16.7b). It can be seen that the temperature is heterogeneous in the cavity: air at the bottom is cooler than that at the top. The mean air temperature calculated from 25 measurements is also shown in Figure $16.7 \mathrm{~b}$ and the average value of this temperature over $24 \mathrm{~h}$ $\left(T_{\text {ai }}\right)$ is $6.3^{\circ} \mathrm{C}$ (minimum value $3.8^{\circ} \mathrm{C}$ and maximum value $8.3^{\circ} \mathrm{C}$ ).

The wall temperature variations are shown in Figure 16.7c, the mean value at the top level being $9.1^{\circ} \mathrm{C}$, at the middle level $5.4^{\circ} \mathrm{C}$ and at the bottom level $5.7^{\circ} \mathrm{C}$. The average value of these three temperatures $\left(T_{\mathrm{wi}}\right)$ is $6.7^{\circ} \mathrm{C}$.

\subsubsection{Temperature in Freezer}

The air temperature fluctuations in a domestic freezer equipped with one compressor are generally more significant than those equipped with two compressors. An example of these fluctuations is presented in Figure 16.8. Both refrigerators are two-door models, with a refrigerating compartment on the top and a freezing compartment on the bottom. Air-temperature stratification can be observed in the compartment in both cases. The air on the top shelf was slightly higher than that on the middle one (cold air is heavier). The characteristics of these two refrigerators are presented in Table 16.1. The wall of the freezing compartment of these refrigerators was composed of an inner liner $(1 \mathrm{~mm}$ of polystyrene, $\lambda=0.15 \mathrm{~W} \cdot \mathrm{m}^{-1} \cdot \mathrm{K}^{-1}$ ), foam (polyurethane, $\lambda=0.02 \mathrm{~W} \cdot \mathrm{m}^{-1} \cdot \mathrm{K}^{-1}, 5.8 \mathrm{~cm}$ for the one compressor refrigerator and $6.3 \mathrm{~cm}$ for the two compressor refrigerator) and a metal outer sheet $(0.7$ $\left.\mathrm{mm}, \lambda=50 \mathrm{~W} \cdot \mathrm{m}^{-1} \cdot \mathrm{K}^{-1}\right)$. It was clearly shown, in this example, that the temperature was less stable in the freezing compartment of the one compressor refrigerator.

\subsubsection{Heat Transfer Modes in Domestic Refrigerator}

In an empty refrigerator, cold air near the evaporator flows downward and warm air near the door and the other side walls flows upward (Figure 16.9). The heat exchanges inside the cavity 
(a)

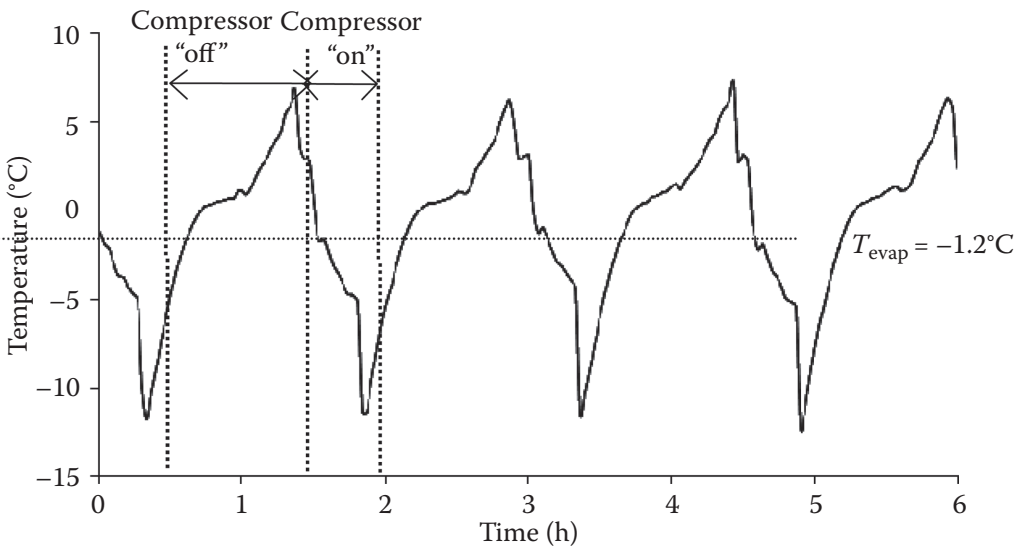

(b)

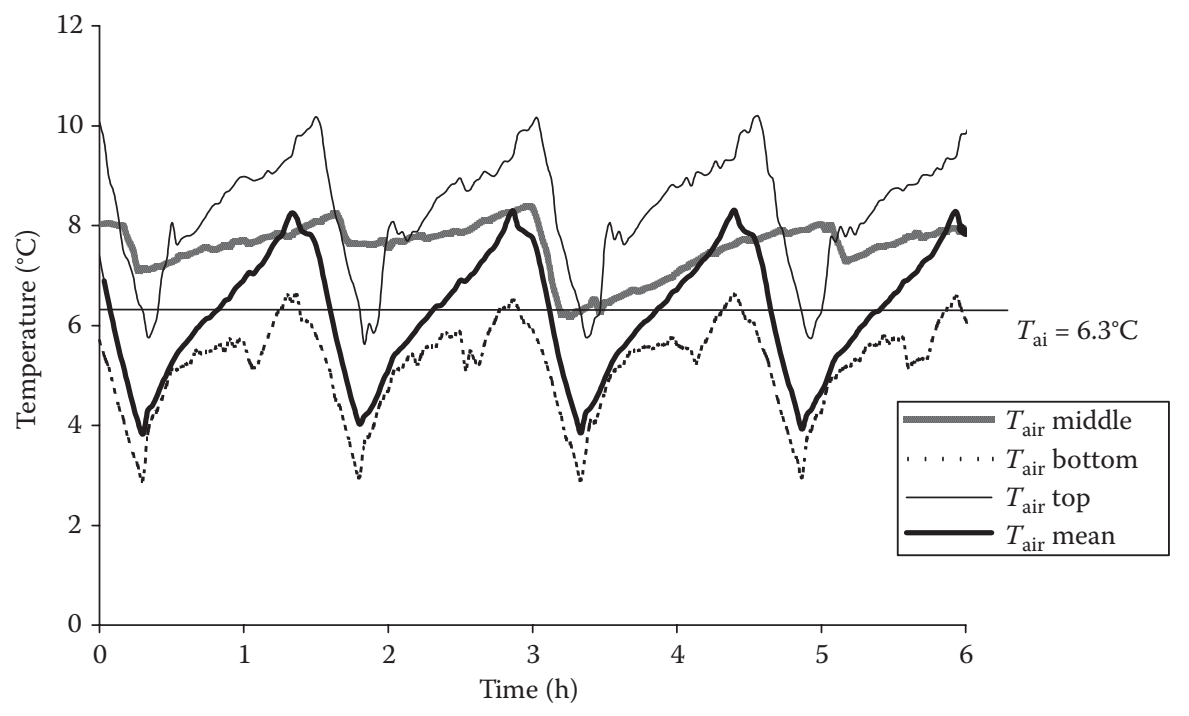

(c)

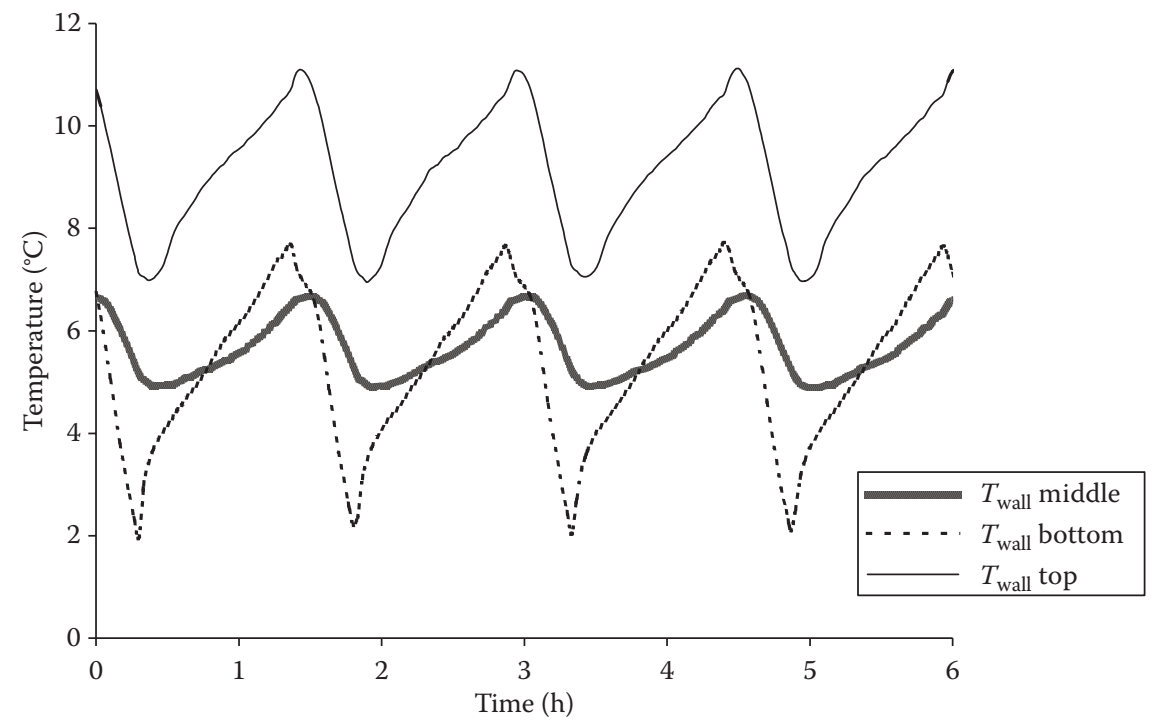

FIGURE 16.7 Example of temperature variations in a refrigerating compartment of one compressor appliance for a thermostat setting at $6^{\circ} \mathrm{C}$ : (a) evaporator wall, (b) air temperature, (c) wall temperature. 
in : Mathematical Modelling of Food Processing, Mohammed M. Farid (ed.) ; CRC Press; Boca Raton, USA; 445-474; 2010

Heat Transfer and Air Flow in a Domestic Refrigerator
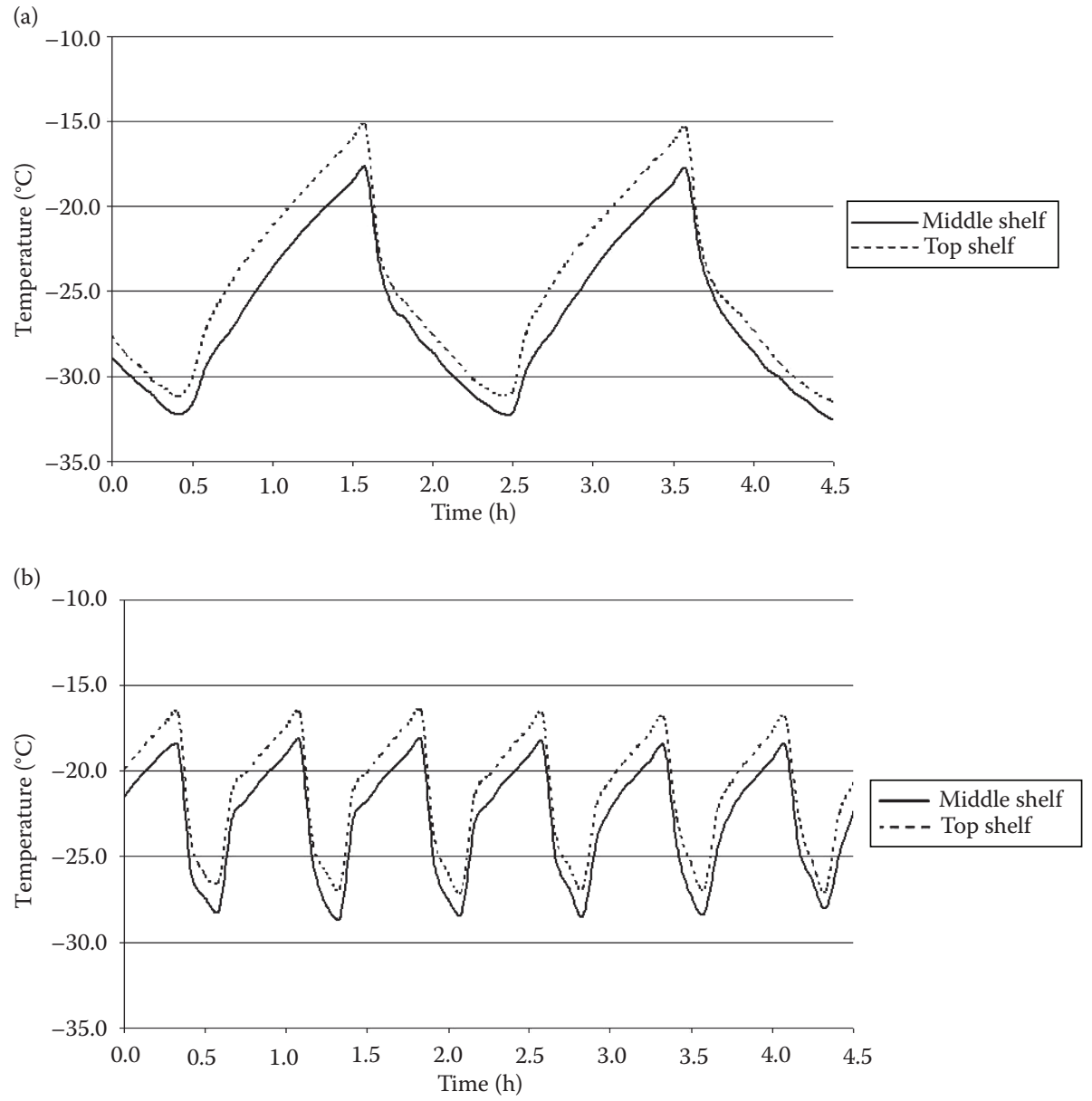

FIGURE 16.8 Example of air-temperature variations in the freezing compartment: (a) one compressor refrigerator, and (b) two compressor refrigerator.

\section{TABLE 16.1}

\section{Characteristics of Refrigerators}

\begin{tabular}{|c|c|c|}
\hline & One-compressor Refrigerator & Two-compressor Refrigerator \\
\hline $\begin{array}{l}\text { External dimensions } \\
(\text { height } \times \text { width } \times \text { depth })\end{array}$ & $185 \mathrm{~cm} \times 60 \mathrm{~cm} \times 60 \mathrm{~cm}$ & $195 \mathrm{~cm} \times 60 \mathrm{~cm} \times 60 \mathrm{~cm}$ \\
\hline $\begin{array}{l}\text { Internal dimensions of the freezing } \\
\text { compartment }\end{array}$ & $62 \mathrm{~cm} \times 48 \mathrm{~cm} \times 38 \mathrm{~cm}$ & $64 \mathrm{~cm} \times 47 \mathrm{~cm} \times 42 \mathrm{~cm}$ \\
\hline Thermostat setting & $\begin{array}{l}+4^{\circ} \mathrm{C} \text { (impossible to set the } \\
\text { temperature of freezing compartment) }\end{array}$ & $\begin{array}{l}+4^{\circ} \mathrm{C} \text { (refrigerating compartment) } \\
\text { and }-18^{\circ} \mathrm{C} \text { (freezing compartment) }\end{array}$ \\
\hline Power of compressor & $120 \mathrm{~W}$ & $160 \mathrm{~W}$ \\
\hline
\end{tabular}

are governed by natural convection between internal walls and air, radiation between evaporator and the other walls and conduction within the walls. ${ }^{35}$ In the case of a refrigerator filled with products, the products are cooled by natural convection, radiation between the surface of the products and the internal walls of the refrigerator, and through conduction and radiation between products. 


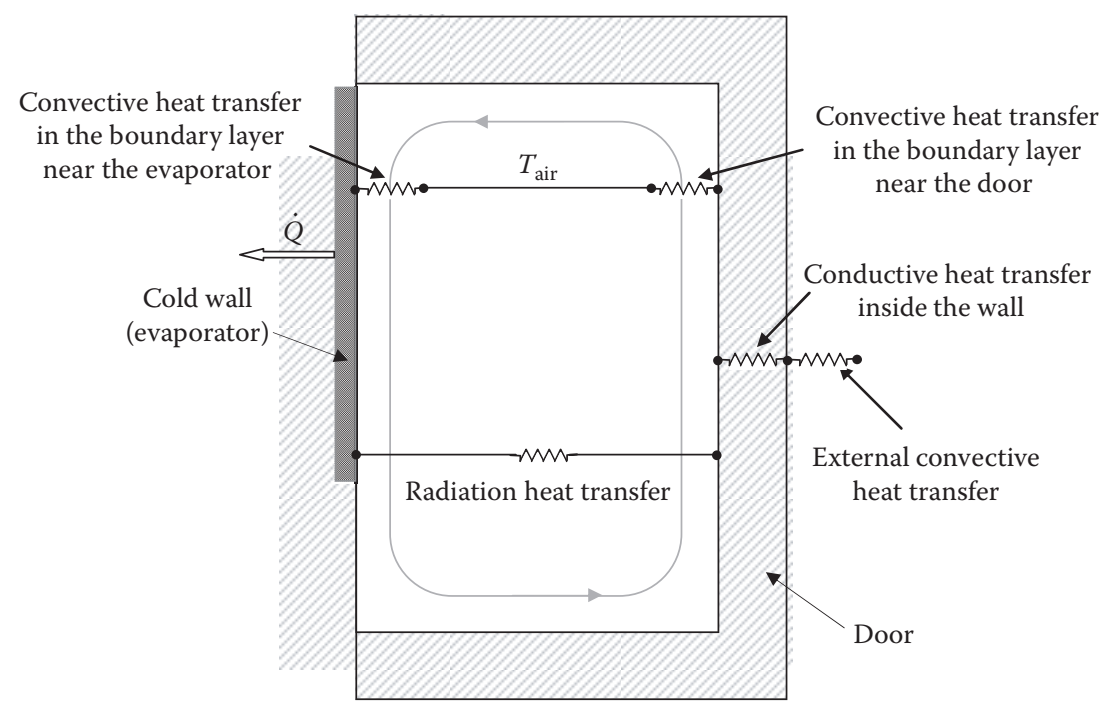

FIGURE 16.9 Various heat exchange modes and airflow inside a domestic refrigerator.

\subsection{EXAMPLE OF HEAT TRANSFER ANALYSIS IN A TYPICAL REFRIGERATOR}

In order to study heat transfer inside a refrigerator, natural convection theories covering the following cases can be applied:

- Rectangular closed cavity representing heat transfer inside the refrigerating compartment

- Cold vertical plate placed in a warm ambience representing exchanges between the evaporator and air

- Rectangular closed cavity partially filled with porous media representing a loaded refrigerator. This case is more complex and the study requires numerical simulations as presented in Section 16.6.

\subsubsection{Empty Refrigerator Considered as being a Closed Rectangular Cavity}

The simplest approach that can be used in order to approximate the transfers inside an empty refrigerator is to consider it as a rectangular cavity. ${ }^{35}$ Circular air circulation is established, cool air close to the evaporator moves downward and hot air in contact with the door moves upward.

In order to simplify the study, the exchanges inside the cavity are initially, considered as a two dimensional problem of heat transfer between a cold vertical wall $\left(T_{\text {evap }}\right)$ and a hot vertical wall $\left(T_{\mathrm{wi}}\right)$. The vertical walls are assumed to have a homogeneous temperature and the horizontal walls are adiabatic. This is a rough approximation because, in fact, only part of the vertical wall of a refrigerator is taken up by the evaporator and heat losses occur through at least three vertical walls.

Despite this, the order of magnitude of the Rayleigh number (Ra) can give some qualitative information regarding the hydrodynamic and thermal boundary layers. The refrigerator described in Section 16.4.1 will be used for the analysis. The aspect ratio $(H / L)$ of this typical refrigerator is equal to 1.8 . The Rayleigh number can be based on height or width, but since $H / L=1.8$, the values are of the same order of magnitude. For simplicity's sake, the walls and air temperatures are assumed to be constant. The difference between the inner wall temperature and the evaporator temperature $\left(\Delta T=T_{\mathrm{wi}}-T_{\text {evap }}\right)$ is equal to $7.9^{\circ} \mathrm{C}$.

The physical properties of air, such as conductivity $(\lambda)$, thermal expansion coefficient $(\beta)$, diffusivity $(\alpha)$ and kinetic viscosity $(v)$, are calculated at the reference temperature $\left(T_{f}\right)$ defined as the 
average temperature of the evaporator and the other walls $\left(T_{f}=275.8 \mathrm{~K}\right)$. The Prandtl number for air is taken constant and equal to 0.72 .

The Rayleigh number based on the width of the refrigerating compartment $(L=0.5 \mathrm{~m})$ and the temperature difference between the evaporator and the other walls $(\Delta T)$ is equal to $1.43 \times 10^{8}$.

Thus, the air flow inside the refrigerator is laminar $\left(\mathrm{Ra}<10^{9}\right)$. This result is in agreement with that of Deschamps et al. ${ }^{30}$ who showed that Ra varies between $10^{8}$ and $10^{9}$ in refrigerators.

As the Rayleigh number is higher than $10^{3}$, a stationary core region can be expected, indicating very low air velocities in the area where food is stored.

For this range of Rayleigh number and aspect ratio, a vertical thermal gradient of approximately $\left(T_{\mathrm{wi}}-T_{\text {evap }}\right) / 2$ is expected, ${ }^{44}$ that is $4^{\circ} \mathrm{C}$ in our case.

These expectations are qualitatively confirmed by wall temperature measurement inside the refrigerator (Figure 16.7c). In particular, a wall temperature difference between the top and bottom levels of $3.4^{\circ} \mathrm{C}$ was observed.

In order to estimate the heat transfer coefficient in our refrigerator, the correlation proposed by Catton, ${ }^{26}$ valid for $1<H / L<2,10^{-3}<\operatorname{Pr}<10^{5}$ and $10^{3}<\left(\operatorname{Ra}_{L} \operatorname{Pr}\right) /(0.2+\operatorname{Pr})$ is used:

$$
\mathrm{Nu}_{L}=\frac{h_{g l} \cdot L}{\lambda}=0.18\left(\frac{\operatorname{Pr}}{0.2+\operatorname{Pr}} \operatorname{Ra}_{L}\right)^{0.29}=38.9
$$

Thus, the overall heat transfer coefficient $\left(h_{\mathrm{g} 1}\right)$ between the hot and cold walls and the refrigerating capacity $(\dot{Q})$ can be estimated as:

$$
\begin{gathered}
h_{\mathrm{g} 1}=1.94 \mathrm{~W} /\left(\mathrm{m}^{2} \cdot{ }^{\circ} \mathrm{C}\right) \\
\dot{Q}=h_{\mathrm{g} 1} \cdot A_{w} \cdot\left(T_{\mathrm{wi}}-T_{\text {evap }}\right)=25.3 \mathrm{~W}
\end{gathered}
$$

The experimental refrigerating capacity was also measured using a fluxmeter (measuring dimension $4 \times 4 \mathrm{~cm}$ ) attached to the surface of the evaporator. The average value of measurements taken every 2 min over $24 \mathrm{~h}$ is $10.4 \mathrm{~W}$, which is significantly lower than the calculated value.

Furthermore, with the 2D approximation and due to the symmetry of the cavity, the average air temperature inside the refrigerator is estimated as $T_{\mathrm{ai}}=\left(T_{\mathrm{wi}}+T_{\text {evap }}\right) / 2=2.8^{\circ} \mathrm{C}$ while the experimental average air temperature is $6.3^{\circ} \mathrm{C}$. The differences are essentially due to the simplifying hypothesis of 2D and steady state heat transfer in the cavity.

This approximate calculation of heat transfer in an air-filled cavity applied to an empty refrigerator gives quantitative results quite different from those observed experimentally. Thus, another approach is proposed using correlations available in the literature results for natural convection between vertical plates and air while taking also into account the effect of radiation.

\subsubsection{Empty Refrigerator Considered as a Combination of Vertical Plates}

Heat transfer in the refrigerator is examined on the basis of the theory of natural convection between air and vertical plates which are the evaporator and the side walls in our case. ${ }^{35}$

The application of these correlations is now presented for heat transfer between the evaporator or side walls and air inside the refrigerator.

\subsubsection{Estimation of the Convective Heat Transfer Coefficient by Natural Convection between the Evaporator and Air $\left(h_{\text {evap }}\right)$}

In order to estimate the heat transfer coefficient, which depends on the Rayleigh number, the measured values of the evaporator and the air temperatures inside the refrigerator are used: $-1.2^{\circ} \mathrm{C}$ and $6.3^{\circ} \mathrm{C}$, respectively. 
The Rayleigh number based on the height of evaporator $\left(H_{\text {evap }}=0.3 \mathrm{~m}\right)$ and the difference between the temperature of the evaporator and that of air is: $\mathrm{Ra}_{\text {evap }}=2.0 \times 10^{7}$.

Since $\mathrm{Ra}<10^{9}$, the correlation proposed by Incropera and Dewitt ${ }^{18}$ for laminar flow is used:

$$
\mathrm{Nu}=0.59 \cdot \mathrm{Ra}^{1 / 4}=39.4, \text { thus } h_{\text {evap }}=3.28 \mathrm{~W} /\left(\mathrm{m}^{2} \cdot{ }^{\circ} \mathrm{C}\right)
$$

\subsubsection{Estimation of the Radiative Heat Transfer Coefficient between the Evaporator and the other Walls $\left(h_{r}\right)$}

Heat transfer by radiation occurs between the evaporator and the other walls. An equivalent radiative heat transfer coefficient $h_{r}$ can be defined. For parallel walls of emissivity near 1:

$$
\begin{gathered}
h_{r}=\sigma \cdot \varepsilon_{1} \cdot \varepsilon_{2} \cdot\left(T_{\text {evap }}^{2}+T_{\text {wi }}^{2}\right)\left(T_{\text {evap }}+T_{\text {wi }}\right) \\
\sigma=\text { Boltzmann constant }=5.67 \times 10^{-8}: \mathrm{W} /\left(\mathrm{m}^{2} \cdot \mathrm{K}^{4}\right)
\end{gathered}
$$

In the case of the refrigerator, the emissivity of the internal surfaces is approximately $\varepsilon_{1}=\varepsilon_{2}=0.9$ and we obtain $h_{r}=3.85 \mathrm{~W} /\left(\mathrm{m}^{2} . \mathrm{K}\right)$.

One can note that the value of the radiative heat transfer coefficient is of the same order of magnitude as that of natural convection. Therefore, it should be taken into account when investigating heat transfer in refrigerators.

\subsubsection{Estimation of the Convective Heat Transfer Coefficient between Air and the Internal Walls of the Refrigerator $\left(h_{\mathrm{wi}}\right)$}

The same approach is used for the side walls as for the evaporator. The Rayleigh number, based on the temperature difference between that of inner side wall and inner air and on the height of the walls is $4.2 \times 10^{7}\left(\mathrm{Ra}<10^{9}\right)$.

The correlation proposed by Incropera and Dewitt ${ }^{18}$ for laminar flow is used:

$$
\mathrm{Nu}_{w}=0.59 \cdot \mathrm{Ra}^{1 / 4}=47.4 \text {, thus } h_{\mathrm{wi}}=1.3 \mathrm{~W} /\left(\mathrm{m}^{2} \cdot{ }^{\circ} \mathrm{C}\right)
$$

\subsubsection{Estimation of the Overall Heat Transfer Coefficient and Refrigerating Capacity}

The thermal resistances of the refrigerator are represented in Figure 16.10.

While considering that the surface of the evaporator, $A_{\text {evap }}$ is $0.5 \times 0.30=0.15 \mathrm{~m}^{2}$ and the total vertical wall surface, $A_{w}$ is $4 \times(0.5 \times 0.9)-0.15=1.65 \mathrm{~m}^{2}$, the values of the heat transfer resistances are:

Heat resistance by natural convection between internal air and the evaporator, $R_{\text {evap }}=1 /\left(h_{\text {evap }}\right.$. $\left.A_{\text {evap }}\right)=2.032^{\circ} \mathrm{C} / \mathrm{W}$.
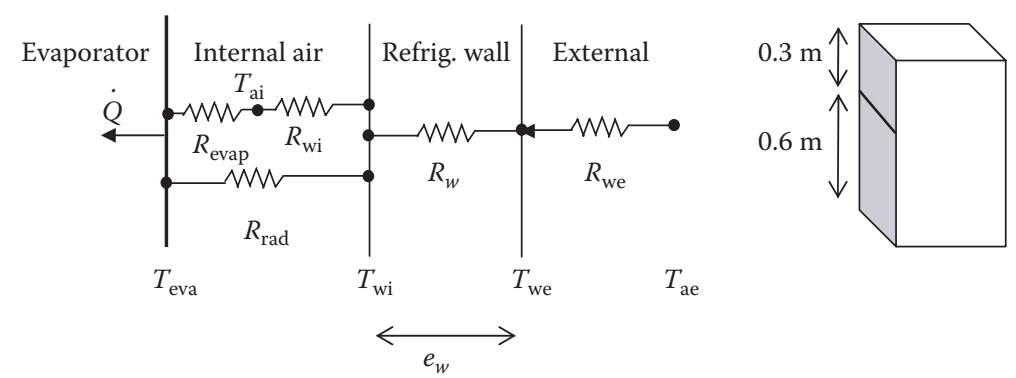

FIGURE 16.10 Thermal resistance between the evaporator and the external ambience. 


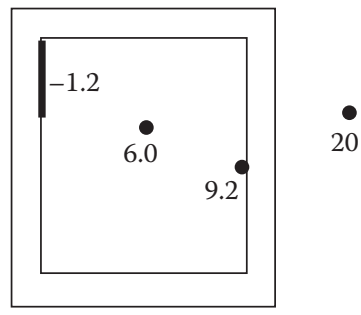

FIGURE 16.11 Estimated internal temperatures $\left({ }^{\circ} \mathrm{C}\right.$ ) of air and walls of the refrigerator (evaporator and ambient temperatures were determined experimentally).

Heat resistance by natural convection between internal air and the walls, $R_{\mathrm{wi}}=1 /\left(h_{\mathrm{wi}}\right.$. $\left.A_{w}\right)=0.466^{\circ} \mathrm{C} / \mathrm{W}$.

Heat resistance by radiation between evaporator and the walls, $R_{\mathrm{rad}}=1 /\left(h_{r} \cdot A_{\text {evap }}\right)=1.732^{\circ} \mathrm{C} / \mathrm{W}$.

Heat resistance by conduction in the walls, $R_{w}=e_{w} /\left(A_{w} \cdot \lambda_{\mathrm{w}}\right)=0.90^{\circ} \mathrm{C} / \mathrm{W}$.

The thermal resistance between the external walls and the ambient air $\left(R_{\mathrm{we}}\right)$ is assumed to be constant:

$$
R_{\mathrm{we}}=1 /\left(h_{\mathrm{ext}} \cdot A_{w}\right)=0.060^{\circ} \mathrm{C} / \mathrm{W}\left(h_{\mathrm{ext}}=10 \mathrm{~W} / \mathrm{m}^{2} /{ }^{\circ} \mathrm{C}\right) .
$$

By using the value of the different heat transfer resistances cited previously, it was found that the overall heat transfer resistance between the evaporator and the external ambience is $R_{\mathrm{g} 1}=1.98^{\circ} \mathrm{C} / \mathrm{W}$ and the refrigerating capacity, $Q=\left(T_{\mathrm{ae}}-T_{\text {evap }}\right) / R_{\mathrm{g} 1}=10.7 / \mathrm{W}$. This value is slightly higher than the measured value $(10.4 \mathrm{~W})$.

The different temperatures can also be evaluated as shown in Figure 16.11.

The predicted internal air temperature is close to measured values, while the predicted wall temperature is higher. The estimations are much more accurate than those of the first approach (2D cavity), but the heat transfer coefficient between air and the walls appears to be underestimated.

\subsubsection{Estimation of the Thickness of the Thermal Boundary Layer Near the Evaporator}

According to the Rayleigh number $\left(\mathrm{Ra}_{\text {evap }}\right)<10^{9}$, one can consider that air flow in the thermal boundary layer is laminar. The mean thickness of the equivalent thermal boundary layer can be estimated as follows:

$$
\delta_{T, \text { eq }}=\frac{\lambda}{h_{\text {evap }}}=\frac{0.025}{3.3}=7.6 \times 10^{-3} \mathrm{~m} \sim 8 \mathrm{~mm}
$$

According to Figure 16.12, it can be observed that there is a zone, inside this boundary layer, where the temperature is below $0^{\circ} \mathrm{C}$. The thickness of this zone is about $2 \mathrm{~mm}$. This result makes it possible to estimate the minimum distance from the evaporator where foods should be placed in order to avoid the freezing.

It should be borne in mind that this calculation is only an estimation of the order of magnitude since three important assumptions are used:

- The temperature of the evaporator is constant at $-1.2^{\circ} \mathrm{C}$, while in reality, it varies within a range of +7 to $-12^{\circ} \mathrm{C}$.

- The temperature of air in the refrigerating compartment is constant and homogeneous at $6.3^{\circ} \mathrm{C}$, while in reality, it varies within a range of $3.8-8.3^{\circ} \mathrm{C}$.

- The evaporator is equivalent to a fine plate, while in reality it is embedded in a wall. 


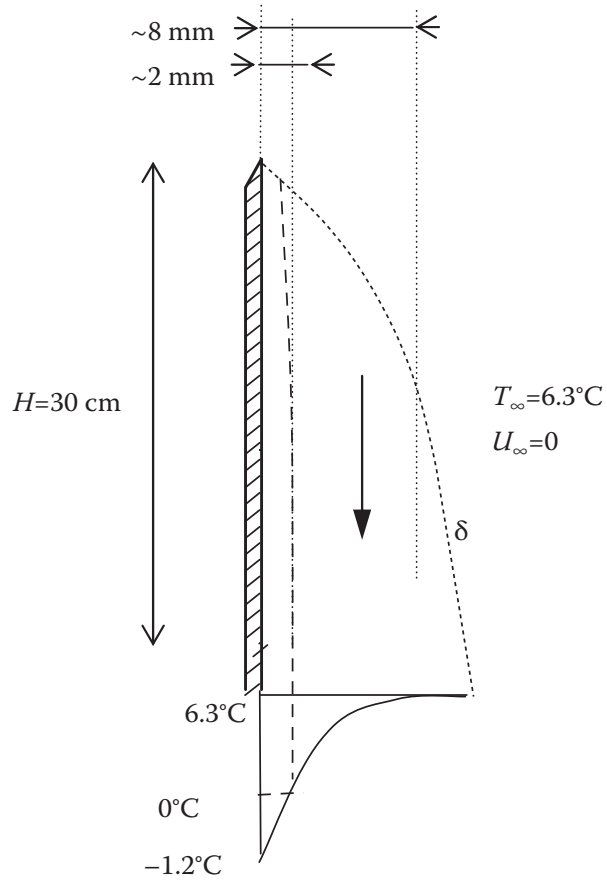

FIGURE 16.12 Thermal boundary layer and temperature profile near a vertical plate representing the evaporator.

It was observed by experiment and by numerical simulation that the heat transfer and airflow in domestic refrigerator are $3 \mathrm{D} .{ }^{45,46}$ To study this more complex $3 \mathrm{D}$ configuration, numerical simulation is presented in the next section.

\subsection{NUMERICAL SIMULATION IN DOMESTIC REFRIGERATOR}

The simple mathematical approach shown in Section 16.5 has limitations. For more thorough study, CFD simulation was carried out within the refrigerating compartment of a domestic refrigerator without a fan. ${ }^{46}$

\subsubsection{Refrigerator Characteristics}

A single-door appliance with only a refrigerating compartment (without a freezer) was considered. Its general characteristics are shown in Table 16.2.

Three cases were studied (Figure 16.13): an empty refrigerator without shelves, empty refrigerator fitted with glass shelves ( $5 \mathrm{~mm}$ thickness, thermal conductivity of glass $0.75 \mathrm{~W} \mathrm{~m}^{-1} \mathrm{~K}^{-1}$ ) and a refrigerator equipped with glass shelves and loaded with a "test product." This product is made of aqueous methylcellulose gel (thermal conductivity $0.5 \mathrm{~W} \mathrm{~m}^{-1} \mathrm{~K}^{-1}$ ) and the dimensions of one package are $10 \times 10 \times 5 \mathrm{~cm}$ (length $\times$ width $\times$ depth). The arrangement of the packages is shown in Figure $16.13 \mathrm{c}$. All experiments were carried out in a temperature-controlled room $\left(20 \pm 0.2^{\circ} \mathrm{C}\right)$. As shown in Figure 16.13, the evaporator is located in the upper part of the cabinet. The indentation observed in the lower right area of the figures represents the compressor placement. To avoid a too complex geometry, the containers for butter, eggs, and bottles usually attached to the door were removed during our experiments. This facilitates the meshing of the refrigerator and the result interpretation. 


\section{TABLE 16.2}

\section{Characteristics of the Refrigerator used for Numerical Simulation}

External dimensions (height $\times$ width $\times$ depth)
Internal dimensions (height $\times$ width $\times$ depth)
Dimensions of the evaporator
Thermostat setting
Number of shelves

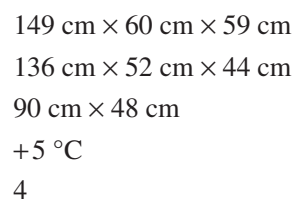

(a)

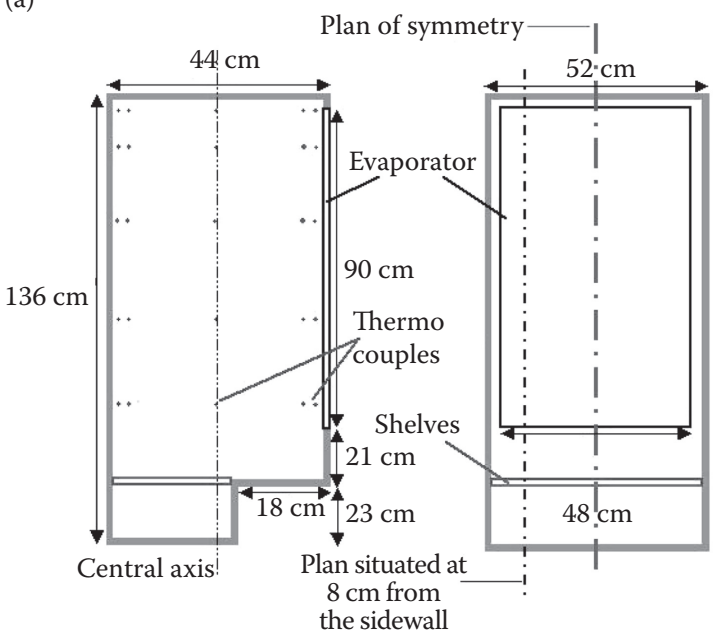

(b)

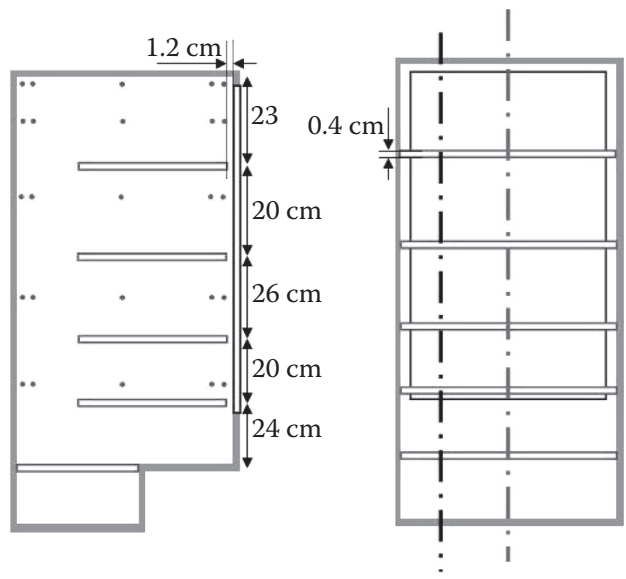

(c)

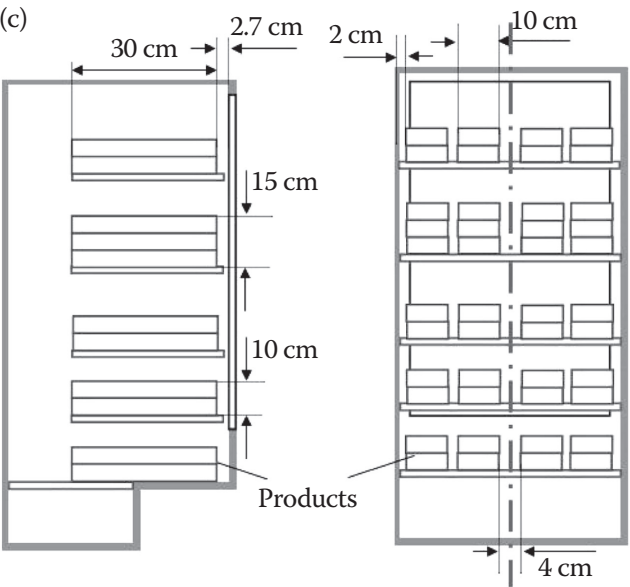

FIGURE 16.13 Domestic refrigerator geometry: (a) empty refrigerator, (b) refrigerator fitted with glass shelves, (c) refrigerator with glass shelves and products.

\subsubsection{Measurement of the Thermal Resistance Of Refrigerator Insulation}

Measurement of the thermal resistance of refrigerator insulation was carried out in a temperaturecontrolled room $\left(6^{\circ} \mathrm{C}\right)$. A heating coil was placed inside the "switch off" refrigerator. The heat supplied to the coil is equal to the heat loss to external air through the walls. The heating power was adjusted in such a manner as to maintain the average internal air temperature at $30^{\circ} \mathrm{C}$. In this 
manner, the average temperature of the insulating walls is almost the same as under real operating conditions. To ensure a homogeneous air temperature inside the refrigerator, a small fan was installed near the heating coil. The internal air temperature $\left(T_{\text {int }}\right.$ controlled at $\left.30^{\circ} \mathrm{C}\right)$, external air temperature $\left(T_{\text {ext }}\right.$ controlled at $\left.6^{\circ} \mathrm{C}\right)$, power supplied to the heating coil $\left(Q_{1}\right)$ and fan $\left(Q_{2}\right)$ were recorded when the steady state was attained (after $12 \mathrm{~h}$ ) and the average values were calculated over $3 \mathrm{~h}$. Thus, the thermal resistance of the refrigerator insulation can be calculated knowing $Q_{1}+Q_{2}$ and $T_{\text {int }}-T_{\text {ext }}$.

The measurement was used afterward for the boundary conditions in the CFD simulation. In fact, this experimental thermal resistance takes into account the thermal resistance between external air and internal walls. Therefore, a correction was undertaken on the measured value by subtracting the thermal resistance between internal air and walls. This correction is weak because the thermal resistance between air and internal wall represents only around $7 \%$ of the overall thermal resistance (between external and internal air). In our case, the internal convective heat transfer coefficient was assumed to be about $10 \mathrm{~W} \mathrm{~m}^{-2} \mathrm{~K}^{-1}$.

\subsubsection{Temperature Measurement}

Air and product temperatures were measured experimentally using calibrated thermocouples (T-type) placed in different positions of the symmetry plane of the refrigerator and on the plane situated at $8 \mathrm{~cm}$ from side wall (Figure 16.13). On each plane, the air temperature was measured at five height levels $(31.0,61.0,94.0,114.5,134.5 \mathrm{~cm})$ and for each height, five air temperature measurements were recorded $(1,2,21.5,42,43 \mathrm{~cm}$ from the evaporator). Firstly, the refrigerator operated over $24 \mathrm{~h}$ to ensure stabilization conditions, then the temperatures were recorded every $2 \mathrm{~min}$ for 24 $\mathrm{h}$ and the average value was calculated at each measurement point. An example of temperature evolution inside the refrigerator is shown in Figure 16.14. It can be seen that the evaporator temperature varies from $-16^{\circ} \mathrm{C}$ to $+7^{\circ} \mathrm{C}$, due to the thermal inertia, the air temperature varies less, from $+3.5^{\circ} \mathrm{C}$ to $+7^{\circ} \mathrm{C}$, and the wall temperature varies from $4^{\circ} \mathrm{C}$ to $9^{\circ} \mathrm{C}$.

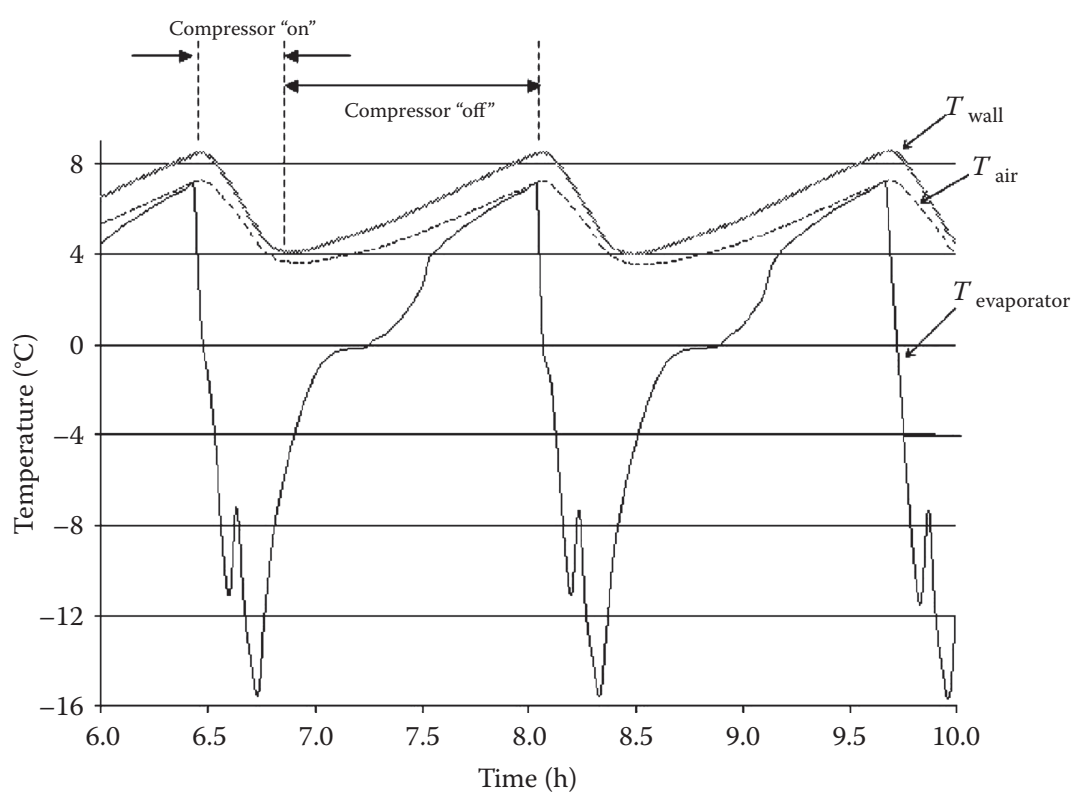

FIGURE 16.14 Air (average value on the symmetry plan), side wall (average value of three measurements: top, middle and bottom levels) and evaporator temperature changes in the empty refrigerator without shelves (thermostat setting at $5^{\circ} \mathrm{C}$ ). 


\subsubsection{Modeling}

\subsubsection{Main Assumptions and Boundary Conditions}

In the present study, the Rayleigh number $(\mathrm{Ra})$ is about $6 \times 10^{8}$ (estimation based on the height of the evaporator and the temperature difference between the internal air and the cold-wall surface). Laminar flow assumption was made for the flow regime in our simulation since $\mathrm{Ra}<10^{9}$. Furthermore, several numerical studies showed that turbulence does not change the predicted air temperature pattern. ${ }^{30,47}$ Boussinesq approximation was used since the air temperature variation is small compared with the mean absolute value.

The thermal boundary conditions are based on experimental data:

- Uniform global heat transfer coefficient between external air and internal wall (0.34 W $\left.\mathrm{m}^{-2} \mathrm{~K}^{-1}\right)$.

- Constant external air temperature $\left(20^{\circ} \mathrm{C}\right)$.

- Constant evaporator temperature $\left(-0.5^{\circ} \mathrm{C}\right)$ which is the average value during "on" and "off" running cycles of compressor. This constant temperature is used in order to avoid excessive complexity in the calculation and to reduce calculation time.

The simulations were performed with the finite volume method using CFD software Fluent 6.1 with the resolution parameters indicated in Table 16.3.

Transient simulation was performed but only the results obtained after simulation convergence were used for the comparison with the experimental values.

\subsubsection{Mesh}

Structured mesh was used to describe the geometry of the refrigerator. Finer meshes were used near walls, shelves and products. The number of cells used in each case is shown in Table 16.4 and mesh structures are shown in Figure 16.15. To ensure that the results were not influenced by the cell numbers, a sensitivity study was carried out beforehand. Only one half of the refrigerator was meshed because of the symmetry plane.

\subsubsection{Discrete Ordinate (DO) Method for Radiation}

The discrete ordinate (DO) method ${ }^{48}$ was successfully used to simulate the coupling of convection and radiation in closed cavity. ${ }^{49,50}$

This model can take into account the participating medium. However, in our case, air is considered as transparent (with neither absorption nor diffusion). The general equation of heat transfer by radiation (in a given $\vec{s}$ direction) is

$$
\vec{\nabla} \cdot(I(\vec{r}, \vec{s}) \vec{s})=0
$$

$I(\vec{r}, \vec{s})$ is radiative intensity in $\vec{s}$ direction (at $\vec{r}$ position) ( $\mathrm{W} \mathrm{m}^{-2}$ per unit solid angle).

For a gray surface of emissivity $\varepsilon_{r}$, the net radiative flux leaving the surface is

$$
\Phi_{\text {rad_out }}=\left(1-\varepsilon_{r}\right) \underbrace{\int_{\vec{s} \cdot \vec{n}>0} I_{\text {in }} \vec{s} \cdot \vec{n} d \Omega}_{\text {incident flux }}+\varepsilon_{r} \sigma T_{s}^{4}
$$

The walls are assumed as gray diffuse: $I_{\text {out }}=\phi_{\text {rad_out }} / \pi$

$I_{\text {in: }}$ : intensity of incident radiation in $\vec{s}$ direction (at $\vec{r}$ position)

$I_{\text {out }}$ : intensity of radiation leaving the surface (at $\vec{r}$ position)

$\vec{n}:$ normal vector

$T_{s}$ : surface temperature, $\mathrm{K}$

$\Omega$ : solid angle 
in : Mathematical Modelling of Food Processing, Mohammed M. Farid (ed.) ; CRC Press; Boca Raton, USA; 445-474; 2010

$\begin{aligned} & \text { TABLE 16.3 } \\ & \text { Resolution Parameters used in Simulation } \\ & \text { Relaxation Factor }\end{aligned}$
$\begin{array}{lcl} & \text { Type of Discretization } \\ \text { Pressure } & 0.8 & \text { Presto } \\ \text { Density } & 1 & - \\ \text { Gravity forces } & 1 & - \\ \text { Momentum } & 0.2 & \text { Second order upwind } \\ \text { Energy } & 1 & \text { Second order upwind } \\ \text { Radiation } & 1 & - \\ \text { Pressure-velocity } & - & \text { Simple }\end{array}$

TABLE 16.4

Number of Cells used for the Simulations

$\begin{array}{lcccr}\text { Mesh Number } & \text { Height } \mathbf{( 1 3 6} \mathbf{~ c m}) & \text { Half width } \mathbf{( 2 6} \mathbf{~ c m}) & \text { Depth } \mathbf{( 4 4} \mathbf{~ c m}) & \text { Total } \\ \text { Empty refrigerator } & 138 & 28 & 66 & 255,024 \\ \text { Refrigerator with shelves } & 222 & 28 & 66 & 410,256 \\ \text { Refrigerator with shelves and products } & 240 & 62 & 74 & 1,101,120\end{array}$

(a)

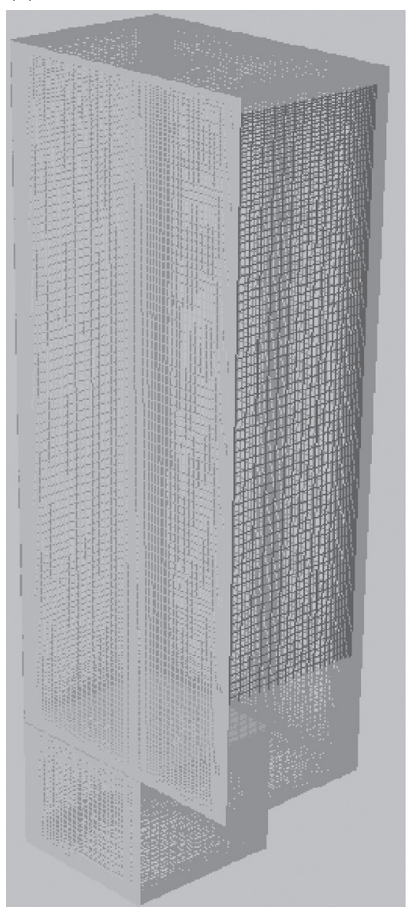

(b)

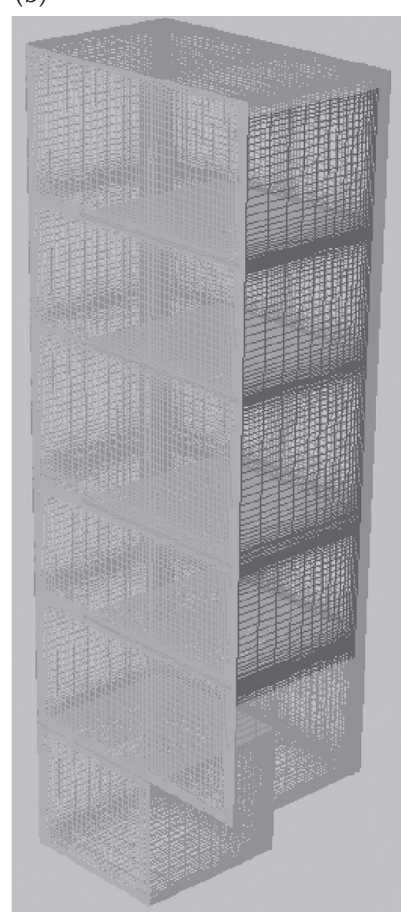

(c)

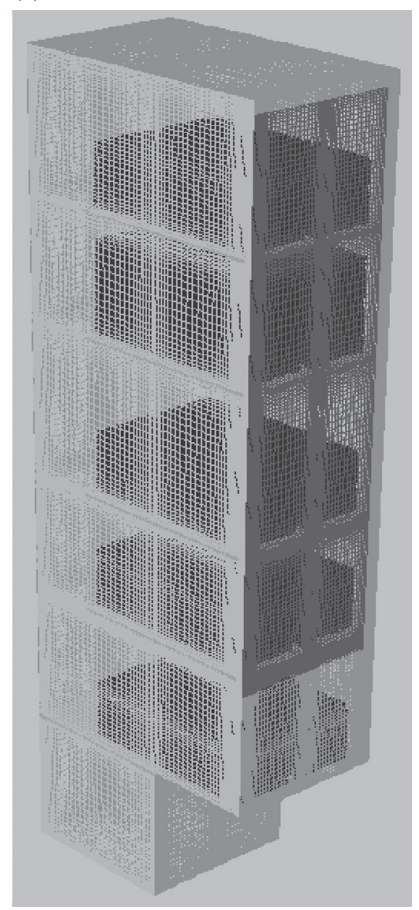

FIGURE 16.15 Mesh structure: (a) empty refrigerator, (b) refrigerator fitted with glass shelves, (c) refrigerator loaded with the "test product." 
A sensitivity study of solid angle discretization was carried out beforehand in order to ensure that the simulation results were not influenced by the number of solid angle subdivisions.

\subsubsection{Numerical Results (Taking into Account Radiation)}

The results presented in this paragraph concern simulation, which takes into account heat transfer by convection between walls and air and by radiation between the internal walls of the refrigerating compartment. Two results will be presented: air temperature and velocity fields. A comparison between numerical and experimental results is carried out only for temperature. In fact, air velocity in a real refrigerator is difficult to measure with precision in practice.

\subsubsection{Temperature Fields}

The temperature fields obtained from simulations for the different cases studied are shown in Figure 16.16. Considering only the main cavity (excluding the vegetable box), for all cases, thermal stratification is observed with the cold zone at the bottom $\left(\sim 2^{\circ} \mathrm{C}\right)$ of the refrigerating compartment and the warm zone at the top $\left(8-9^{\circ} \mathrm{C}\right)$. In addition, a cold zone is also observed along the back wall. This is related to cold air coming from the evaporator. When the refrigerator is loaded with products, the temperature of the product located near the evaporator is lower than that located near the door. In the top half of the compartment, the temperature is relatively homogeneous at a given height (except in the boundary layers near the walls). The temperature of the vegetable box is almost constant for all cases studied $\left(\sim 8^{\circ} \mathrm{C}\right)$.

The temperature field is slightly influenced by the presence of obstacles: shelves and products. A slightly lower temperature is observed at the bottom and a slightly higher one at the top compared with the empty refrigerator case. This is due to the fact that the shelves and/or the products slowed down the air circulation in the central zone of the refrigerator. The presence of shelves and/or products also influenced the main air circulation in the boundary layers situated along the evaporator and the side walls. However, this influence is weak because of the presence of air spaces between the shelves and the vertical walls $(1.2 \mathrm{~cm}$ between the back wall and the shelves), which facilitates the air flow. In our previous study, it was found that the thickness of the boundary layer was less than $2 \mathrm{~cm} .{ }^{45}$

In addition to the overall thermal stratification in the cavity, stratification is also observed in each gap between two shelves or between a shelf and a product. It is to be emphasized that for the refrigerator loaded with the "test product," the symmetry plane is located in the gap between two piles. This explains why the packages are invisible on this plane (Figure 16.16c). On the plane situated at $8 \mathrm{~cm}$ from a side wall which cuts the product pile (Figure 16.16d), a cold product zone near the evaporator can be clearly distinguished. This is related to the blockage of cold air by the product.

The average and maximum air temperatures in all cases are reported in Table 16.5. The air temperatures increase with increasing numbers of obstacles.

\subsubsection{Air Velocity Field}

Figure 16.17 presents the air velocity fields on the symmetry plane (Figure 16.17a-c) and on the plane situated at $8 \mathrm{~cm}$ from the side wall (Figure 16.17d) for the different cases studied. Considering only the main cavity (excluding the vegetable box), for all cases, the main air circulation is observed near the walls, and constitutes a recirculation loop. Air flows downward along the evaporator while its velocity increases along the course to attain a maximum value at the bottom of the refrigerator $\left(u_{\max } \approx 0.2 \mathrm{~m} \mathrm{~s}^{-1}\right)$. Air then flows upward along the door and the side walls of the refrigerator while its velocity decreases progressively and becomes stagnant at the top of the refrigerator. This observation is in agreement with the air temperature field shown in Figure 16.16, with cold air located at the bottom of the cavity and warm air at the top. It can also be observed that there is a weak horizontal air flow from the door to the evaporator. However, the air velocity at the center of the cavity is very 
(a)

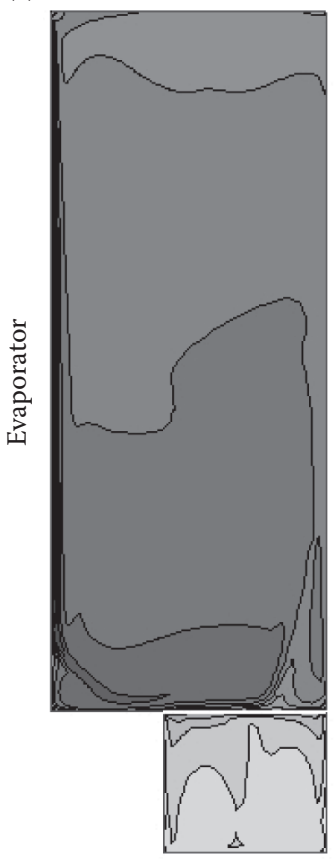

(c)

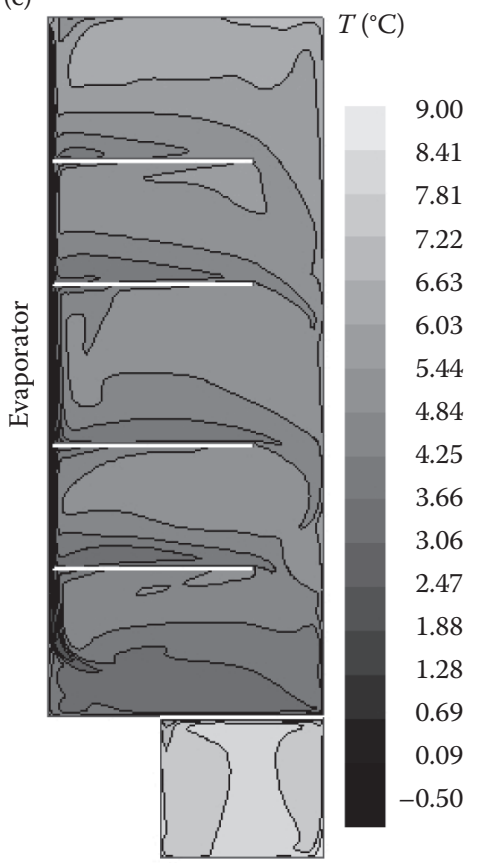

$T\left({ }^{\circ} \mathrm{C}\right)$ (b)

8.20

7.66

7.11

6.57

6.02

5.48

4.94

4.39

3.85

3.31

2.76

2.22

1.67

1.13

0.59

0.04

$-0.50$

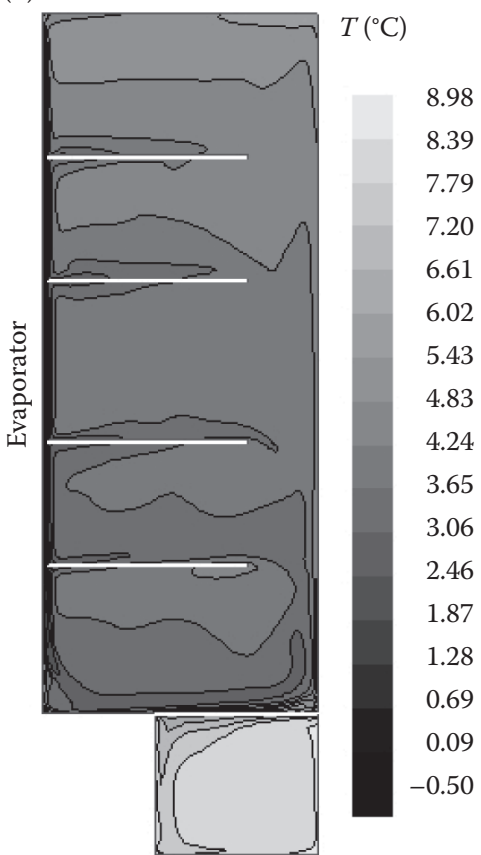

(d)

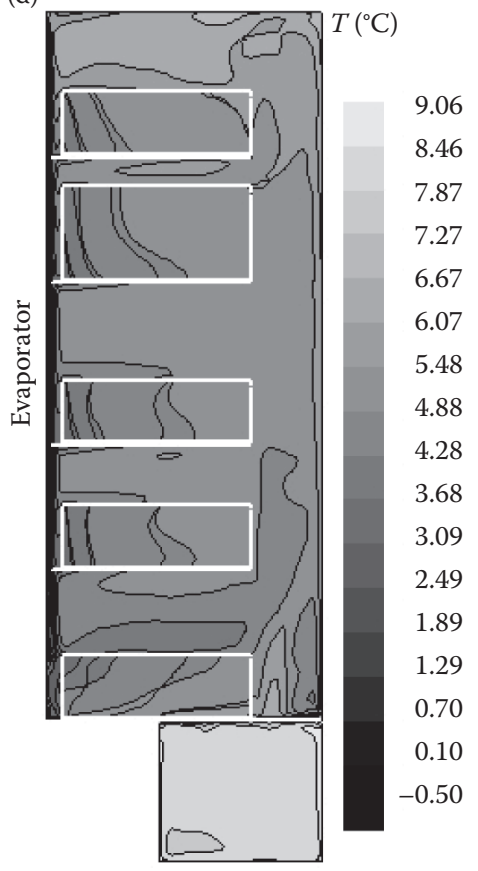

FIGURE 16.16 Predicted temperature fields $\left({ }^{\circ} \mathrm{C}\right)$ : (a) on the symmetry plan of empty refrigerator, (b) on the symmetry plan of refrigerator with glass shelves, (c) on the symmetry plan of refrigerator loaded with products, (d) on the plan situated at $8 \mathrm{~cm}$ from the side wall of refrigerator loaded with products.

low $\left(<0.04 \mathrm{~m} \mathrm{~s}^{-1}\right)$. In the case of the refrigerator fitted with glass shelves, in addition to the main air flow along the walls as mentioned previously, there are also small air loops between the shelves. For the refrigerator loaded with products, air flows in the gaps between the shelves and the products (Figure 16.17d). 
TABLE 16.5

Average and Maximum Air Temperatures for the Three Simulations

$\begin{array}{lccc} & \begin{array}{c}\text { Average Temperature in } \\ \text { the Main Cavity }\left({ }^{\circ} \mathbf{C}\right)\end{array} & \begin{array}{c}\text { Maximum Temperature } \\ \text { in the Main Cavity }\left({ }^{\circ} \mathbf{C}\right)\end{array} & \begin{array}{c}\text { Average Temperature in } \\ \text { the Vegetable Box }\left({ }^{\circ} \mathbf{C}\right)\end{array} \\ \text { Empty refrigerator } & 3.8 & 8.2 & 7.4 \\ \text { Refrigerator with glass shelves } & 4.0 & 9.0 & 8.2 \\ \text { Refrigerator with glass shelves } & 5.1 & 9.1 & 8.0 \\ \text { and products } & & & \\ \end{array}$

It should be remembered that the containers attached to the door were not represented in our study. In practice these containers are an obstacle to airflow along the door and tend to reduce the air velocity in this area.

Considering the vegetable box, one or two air recirculation loops were observed (Figure 16.17). This is due to the presence of the glass shelf (cold wall), which separates the vegetable box from the main cavity, and the five other walls which are warmer (heat loss through these walls).

\subsubsection{Comparison with Numerical Simulation without Radiation}

Figure 16.18 presents the air temperature field on the symmetry plane obtained by simulation without taking into consideration radiation (between internal walls of the refrigerating compartment, shelves and product surface). It was observed that overall the temperature field is similar to that present when radiation is taken into account (a cold zone at the bottom and a warm zone at the top). However, stratification is more pronounced without radiation, and this leads to a higher temperature at the top of the cavity. In fact, for an empty refrigerator, the maximum temperature rises from $8^{\circ} \mathrm{C}$ (with radiation) to $15^{\circ} \mathrm{C}$ (without radiation). This temperature increase can be explained by the fact that, without radiation, there is no heat exchange between the warm top wall and the other colder walls, particularly the evaporator wall. This contributes to a high air temperature at the top position. When radiation is taken into account, the heat exchange between the top wall and the other walls tends to reduce the top wall temperature and consequently reduces air temperature near this wall. From a microbiological point of view, the growth rate is much higher at $15^{\circ} \mathrm{C}$ than at $8^{\circ} \mathrm{C}$. It is therefore necessary to take into consideration radiation in the simulation in order to better describe the phenomena occurring in domestic refrigerators.

\subsubsection{Comparison between the Measured and Predicted Air Temperature}

Figure 16.19 presents a comparison between the measured and predicted air temperature results (with and without taking into account radiation). It can be seen that the simulation results with radiation agreed with the experimental values to a greater extent, while simulation without radiation overestimated the air temperature, particularly at the top of the refrigerator. The peaks observed on the temperature profile in the presence of shelves and/or products can be explained by the higher conductivity of glass compared with air and by the cold air flow along the upper sides of the shelves.

The agreement between the experimental and simulation results is relatively poor in the case of a loaded refrigerator, even though the radiative heat exchange between the product and the walls was taken into account. This may be explained by the geometry complexity. Further grid refinement could lead to a better agreement, but the computing time is already very excessive (about 8 days using a cluster of four processors of 2 Gigaoctets (Go) of RAM).

\subsection{CONCLUSIONS}

Several studies illustrate that a large proportion of refrigerators operate at too high temperatures. These refrigerators are often static types (without fan) in which heat is transferred by natural 
(a)

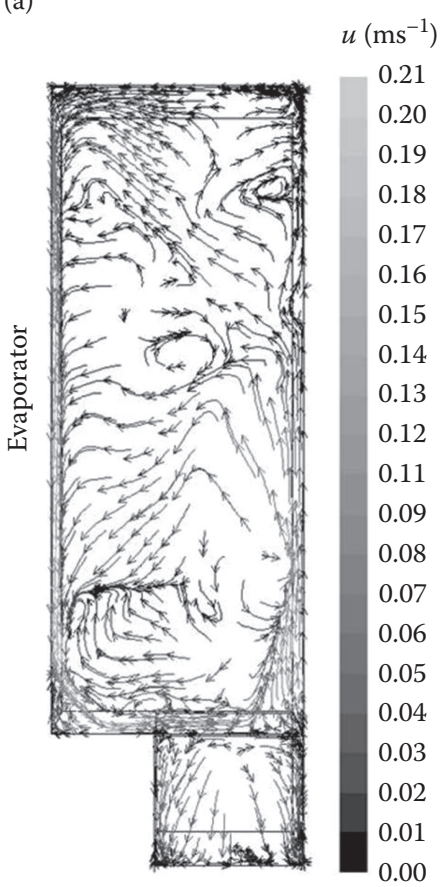

(c)

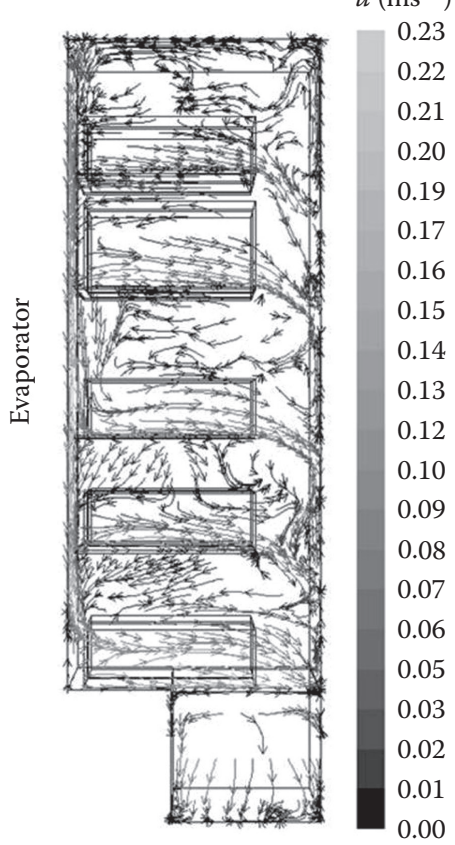

(b)

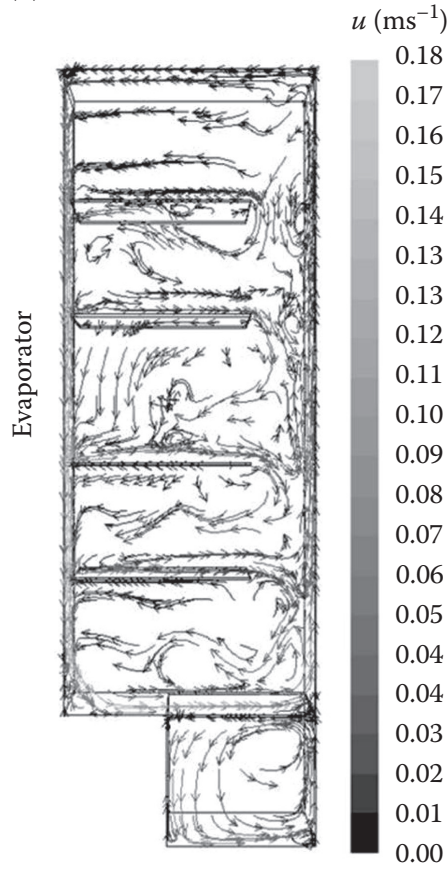

(d)

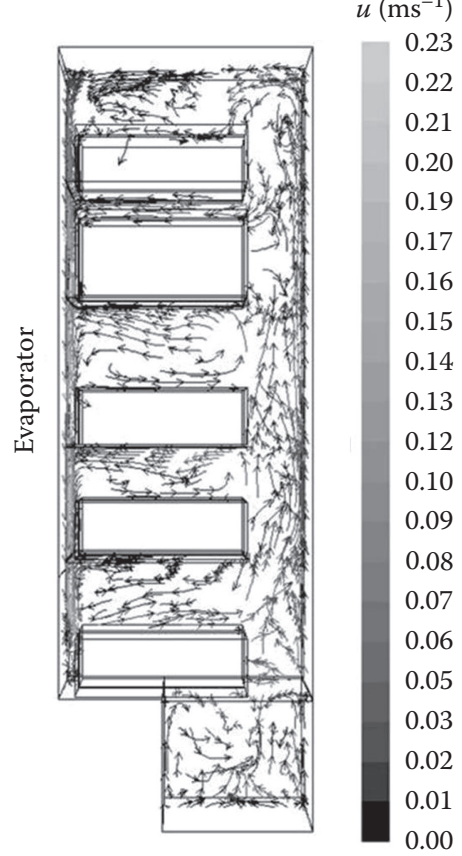

FIGURE 16.17 Path lines: (a) on the symmetry plan of the empty refrigerator, (b) on the symmetry plan of the refrigerator fitted with glass shelves, (c) on the symmetry plan of the refrigerator loaded with products, (d) on the plan situated at $8 \mathrm{~cm}$ from the side wall of refrigerator loaded with products. 
(a)

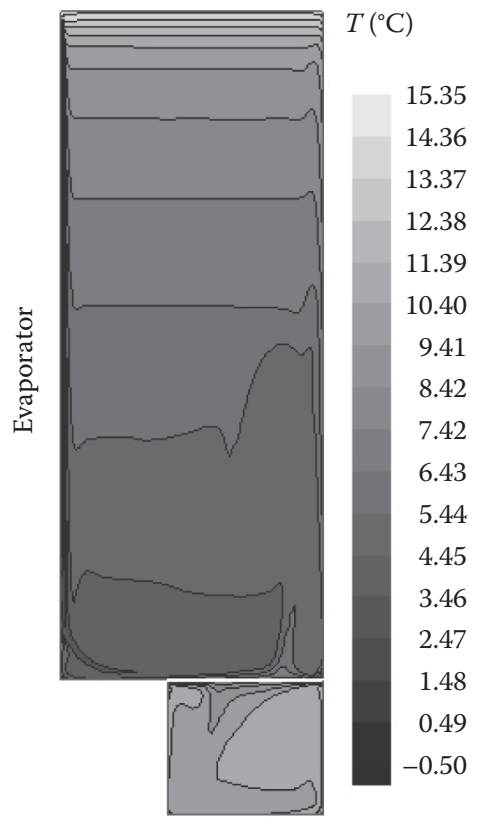

(c)

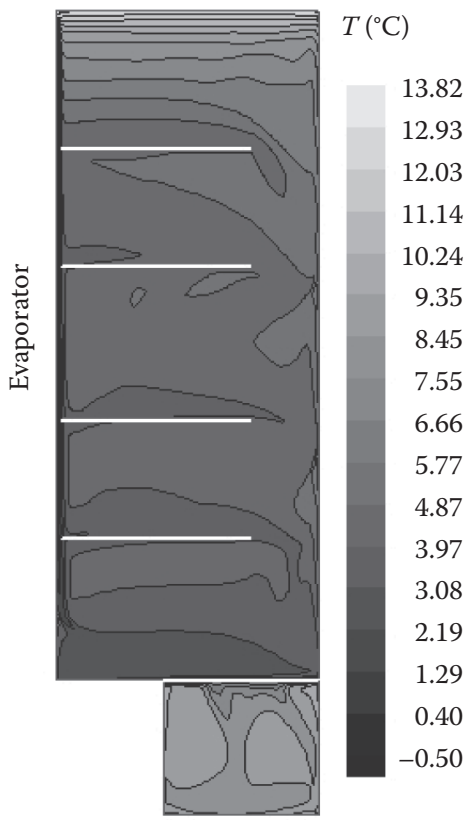

(b)

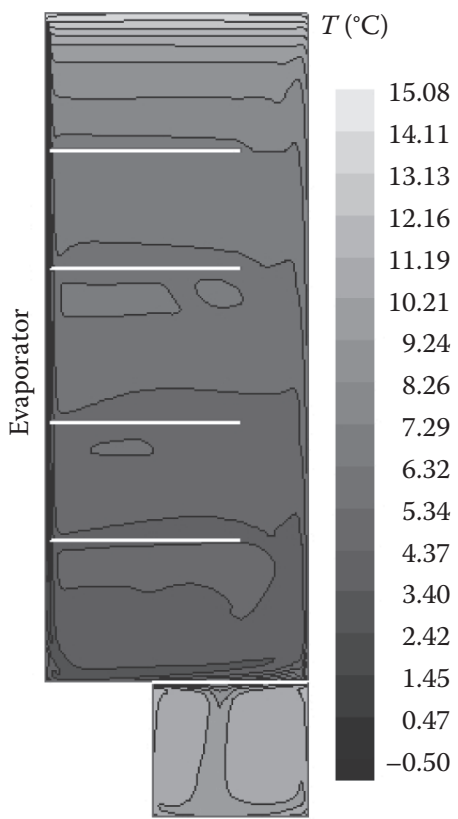

(d)

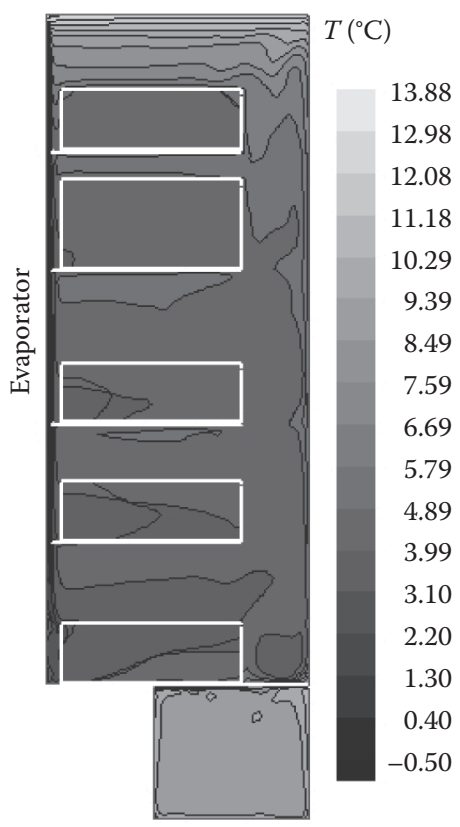

FIGURE 16.18 Temperature field (radiation not taken into account): (a) on the symmetry plan of the empty refrigerator, (b) on the symmetry plan of the refrigerator fitted with glass shelves, (c) on the symmetry plan of the refrigerator loaded with the "test product," (d) on the plan situated at $8 \mathrm{~cm}$ from the side wall of the refrigerator loaded with products. 
(a)

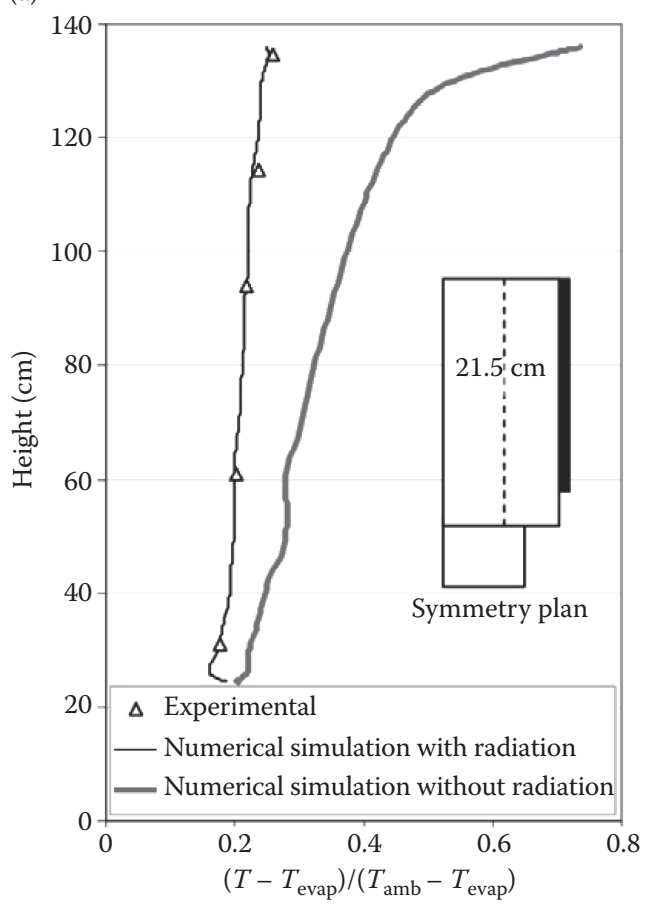

(b)

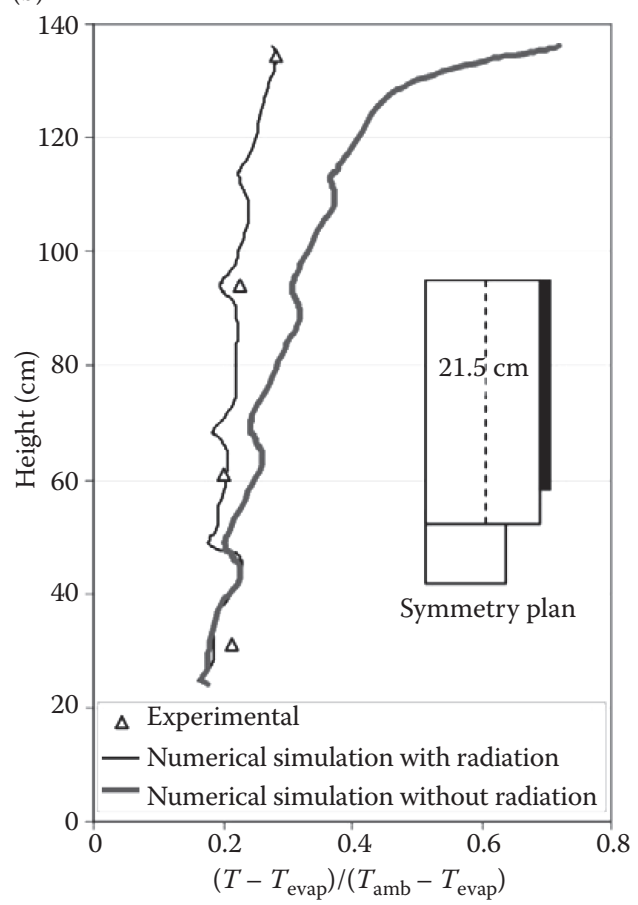

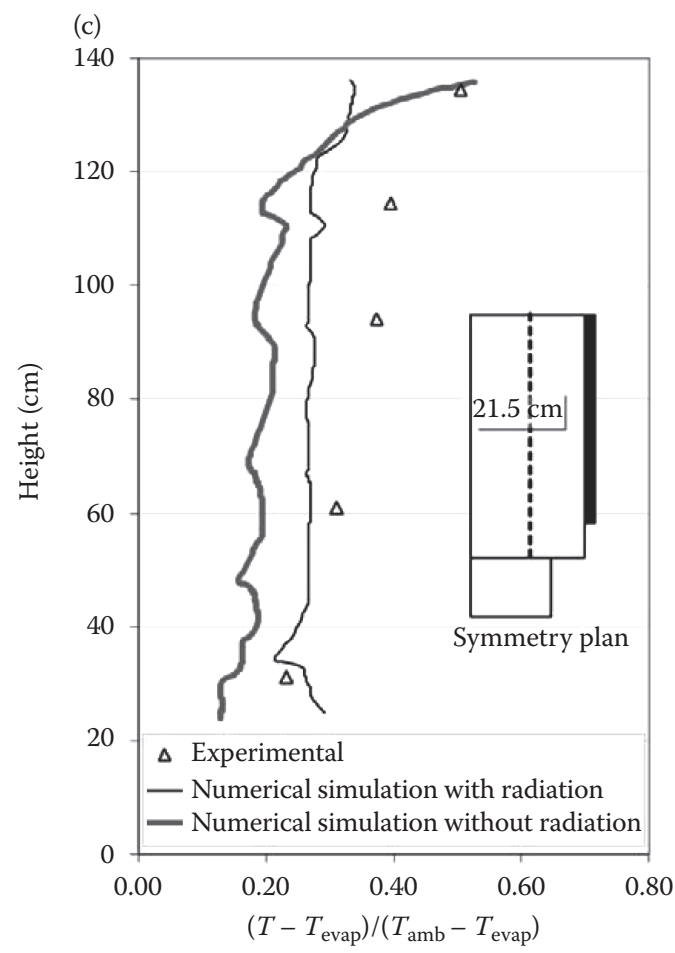

FIGURE 16.19 Comparison between experimental air temperatures and predicted values obtained by simulation with and without radiation: (a) empty refrigerator, (b) refrigerator fitted with glass shelves, (c) refrigerator loaded with products. 
convection. From a food quality and safety point of view, it is necessary to fully understand the mechanism of heat transfer and airflow in refrigerators.

A literature review on natural convection near a vertical plate, in empty and filled cavity was presented in this chapter. Cold production systems and temperature evolutions in domestic refrigerators were shown. Several heat transfer modes which may occur in refrigerators are presented: convection, conduction and radiation. It is to be emphasized that radiation may be the same order of magnitude as natural convection.

The heat transfer by natural convection in a typical domestic refrigerator was analyzed using results recorded in the literature concerning:

- Transfer in a rectangular empty cavity

- Transfer between vertical plates and air

In spite of a simplified hypothesis, the simple mathematical approach provided some useful information on the refrigerator:

- The model, which includes natural convection between the evaporator and air and between the walls and air, radiation between the walls, and conduction inside the walls, gives a good approximation of the required refrigerating capacity and air temperature. This model slightly overestimates the wall temperatures.

- Inside the boundary layer near the evaporator, there is a zone a few millimeters wide in which the temperature is below $0^{\circ} \mathrm{C}$. Therefore, placing food in this zone can lead to freezing.

- Outside the boundary layers, the air is practically stagnant. This means that air circulation is induced near the evaporator and the side walls. However, in the core region, where food is stored, there are low velocities, which do not ensure marked convective heat transfer between air and products.

- The temperature difference between the top and bottom levels of refrigerator can be estimated as being a half of the temperature gradient between the lateral walls and the evaporator. In this type of refrigerator, sensitive food should not be stored on the top shelf.

CFD numerical simulation seems to be a powerful tool to study the complex 3D heat transfer and airflow in refrigerator. Three configurations were studied: an empty refrigerator, an empty refrigerator fitted with glass shelves and a refrigerator loaded with products. When radiation was taken into consideration in simulation, the predicted air temperatures were in good agreement with the experimental values. However, when radiation was not taken into account, the temperature was over-estimated, particularly at the top of the refrigerator. Radiation allows heat exchange, particularly between the top wall and the cold wall (evaporator); consequently, it limits the stratification phenomena.

The obstacles (shelves and/or products) slow down the air circulation in the central zone of the refrigerator and mildly influence the main air circulation along the walls. This is confirmed by the maximum values of air temperature: $8.2^{\circ} \mathrm{C}$ for an empty refrigerator without shelves and $9.1^{\circ} \mathrm{C}$ for a refrigerator loaded with products.

Whatever the configuration studied (empty with/without shelves, loaded with products) for this type of refrigerator, the air temperature at the top of the refrigerator is about $5^{\circ} \mathrm{C}$ higher than the average air temperature, and therefore it is important to avoid placing sensitive products in this position.

The CFD simulation developed by our work can be further used as a tool to study the influence on the temperature and velocity fields of operating conditions: evaporator temperature (parameter related to the thermostat setting by the consumer), dimensions of the evaporator (parameter related to design) and percentage of product-occupied volume in the refrigerating compartment. 


\section{ACKNOWLEDGMENT}

The author would like to thank Professor Denis Flick (AgroParisTech, 16 rue Claude Bernard, 75231 Paris Cedex 05, France) for the review of this chapter.

\section{NOMENCLATURE}

$\mathrm{Cp} \quad$ Thermal capacity $\left(\mathrm{J} / \mathrm{kg} /{ }^{\circ} \mathrm{C}\right)$

h Heat transfer coefficient $\left(\mathrm{W} / \mathrm{m}^{2} /{ }^{\circ} \mathrm{C}\right)$

$\mathrm{H} \quad$ Height (m)

I Intensity of radiation $\left(\mathrm{W} / \mathrm{m}^{2}\right)$ per unit solid angle

L Width or characteristic length (m)

$\mathrm{N}_{\mathrm{RC}} \quad$ Radiation-convection interaction parameter

g Acceleration due to gravity $\left(9.81 \mathrm{~m} / \mathrm{s}^{2}\right)$

$\mathrm{r} \quad$ Radius (m)

$\mathrm{R}$ Thermal resistance $\left({ }^{\circ} \mathrm{C} / \mathrm{W}\right)$ or Radius (m)

$\mathrm{T}$ Temperature $\left({ }^{\circ} \mathrm{C}\right.$ or $\left.\mathrm{K}\right)$

$\Delta \mathrm{T} \quad$ Temperature difference between cold and warm walls, ${ }^{\circ} \mathrm{C}$ or $\mathrm{K}$

$\dot{\mathrm{Q}} \quad$ Refrigerating power (W)

$\mathrm{u} \quad$ Air velocity in flow direction $(\mathrm{m} / \mathrm{s})$

\section{Greek symbol}

$\alpha \quad$ Thermal diffusivity $\left(\mathrm{m}^{2} / \mathrm{s}\right)$

$\beta \quad$ Thermal expansion coefficient $\left(\mathrm{K}^{-1}\right)$

$\lambda \quad$ Thermal conductivity $\left(\mathrm{W} / \mathrm{m} /{ }^{\circ} \mathrm{C}\right)$

$v \quad$ Kinetic viscosity $\left(\mathrm{m}^{2} / \mathrm{s}\right)$

$\delta \quad$ Boundary layer thickness (m)

$\rho \quad$ Density $\left(\mathrm{kg} / \mathrm{m}^{3}\right)$

$\varepsilon \quad$ Emissivity of the wall

$\Omega \quad$ Solid angle

$\Phi \quad$ Radiative flux $\left(\mathrm{W} / \mathrm{m}^{2}\right)$

\section{Subscript}

a Air

$\infty \quad$ Far from walls or bulk

ai Air inside the refrigerator

ae Air outside refrigerator

ext External

evap Evaporator

f Film

gl Overall

$\mathrm{p} \quad$ Product

r Radiation

s Surface

T Thermal

w wall

wi Internal wall

we External wall 
in : Mathematical Modelling of Food Processing, Mohammed M. Farid (ed.) ; CRC Press; Boca Raton, USA; 445-474; 2010

wc Cold wall

wh Hot wall

\section{Dimensionless number}

Pr Prandtl number $=\frac{v}{\alpha}$

$\mathrm{Nu} \quad$ Nusselt number $=\frac{h L}{\lambda}$

$\mathrm{Ra} \quad$ Rayleigh number $=\frac{g \beta \Delta T L^{3}}{\alpha \mathrm{v}}$

\section{REFERENCES}

1. International Institute of Refrigeration (IIR). Report on Refrigeration Sector Achievements and Challenges. International Institute of Refrigeration, Paris, France, 77, 2002.

2. JARN, Japan Air Conditioning, Heating \& Refrigeration, News, Tokyo, Japan, 157, 41, 2005.

3. Billiard, F. Refrigerating equipment, energy efficiency and refrigerants. Bull. Int. Inst. Refrig., 85, 12, 2005.

4. Association Française du Froid (AFF). Livre blanc sur les fluides frigorigènes. Conseil National du Froid, Paris, France, 51, 2001.

5. Redmond, E.C. and Griffith, C. Consumer food handling in the home: a review of food safety studies. J. Food Protection, 66, 130, 2003.

6. Flynn, O.M., Blair, I. and McDowell, D. The efficiency and consumer operation of domestic refrigerators. Int. J. Refrig., 15 (5), 307, (1992)

7. James, S.J. and Evans J. The temperature performance of domestic refrigerators. Int. J. Refrig., 15, 313, 1992.

8. Lezenne Coulander de P.A. Koelkast temperature thuis. Report of the regional Inspectorate for Health Protection, Leeuwarden, The Netherlands, 1994.

9. O'Brien, G.D. Domestic refrigerator air temperatures and the public's awareness of refrigerator use. Int. J. Envi. Health Res., 7, 141, 1997.

10. Sergelidis, D. et al. Temperature distribution and prevalence of Listeria spp. in domestic, retail and industrial refrigerators in Greece. Int. J. Food Microbiol., 34, 171, 1997.

11. Laguerre, O., Derens, E. and Palagos B. Study of domestic refrigerator temperature and analysis of factors affecting temperature: a French survey. Int. J. Refrig., 25, 653, 2002.

12. Jackson, V. et al. The incidence of significant food borne pathogens in domestic refrigerators. Food Control., 18, 346, 2007.

13. Azevedo, I. et al. Incidence of Listeria spp. in domestic refrigerators in Portugal. Food Control, 16, 121, 2005.

14. Olsson, P. and Bengstsson, N. Time temperature conditions in the freezer chain. Report No.309, SIK-The Swedish Food Institute, Gothenberg, Sweden, 1972.

15. Masjuki, H.H. et al. The applicability of ISO household refrigerator-freezer energy test specifications in Malysia. Energy, 26, 723, 2001.

16. Lacerda, V.T. et al. Measurements of the air flow field in the freezer compartment of a top-mount no-frost refrigerator: the effect of temperature. Int. J. Refrig., 28, 774, 2005.

17. Lee, I.S. et al. A study of air flow characteristics in the refrigerator using PIV and computational simulation. J. Flow Visual. Image Proc., 6, 333, 1999.

18. Incropera, F.P. and Dewitt D.P. Fundamentals of Heat and Mass Transfer, $4^{\text {th }}$ Edition. John Wiley and Sons, New Jersey, USA, 1996.

19. Khalifa, A.J.N. Natural convective heat transfer coefficient - a review I. Isolated vertical and horizontal surfaces. Energy Conv. Manag., 42, 491, 2001.

20. Tian, Y.S. and Karayiannis T.G. Low turbulence natural convection in an air filled square cavity : part I: the thermal and fluid flow fields. Int. J. Heat Mass Transfer, 43, 849, 2000.

21. Ampofo, F. and Karayiannis, T.G. Experimental benchmark data for turbulent natural convection in an air filled square cavity. Int. J. Heat Mass Transfer, 46, 3551, 2003. 
22. Betts, P.L. and Bokhari I.H. Experiments on turbulent natural convection in a closed tall cavity. Int. J. Heat Mass Transfer, 21, 675, 2000.

23. Mergui, S. and Penot, F. Convection naturelle en cavité carrée différentiellement chauffée: investigation expérimentale à $\mathrm{Ra}=1.69 \times 109$. Int. J. Heat Mass Transfer, 39, 563, 1996.

24. Armaly, B.F., Li, A. and Nie, J.H. Measurements in three-dimensional laminar separated flow. Int. J. Heat Mass Transfer, 46, 3573, 2003.

25. Ostrach, S. Natural convection in enclosures. J. Heat Transfer, 110, 1175, 1988.

26. Catton, I. Natural convection in enclosures. Proceedings $6^{\text {th }}$ International. Heat Transfer Conference, Toronto, Canada, 6, 13, 1978.

27. Yang, K.T. Natural convection in enclosures. In: Handbook of Single-Phase Heat Transfer. Wiley, New York. 1987.

28. Henkes, R.A. and Hoogendoorn, W.M. Turbulent Natural Convection in Enclosures-A Computational and Experimental Benchmark Study. Editions Europeenes Thermiques et Industries, Paris, France, 1993.

29. Ramesh, N. and Venkateshan S.P. Effect of surface radiation on natural convection in a square enclosure. J. Thermophys. Heat Transfer, 13, 299, 1999.

30. Deschamps, C.J. et al. Heat and fluid flow inside a household refrigerator cabinet. In $20^{\text {th }}$ International Congress of Refrigeration, Sydney, Australia, 1999.

31. Balaji, C. and Venkateshan, S.P. Correlations for free convection and surface radiation in a square cavity. Int. J. Heat Fluid Flow, 15, 249, 1994.

32. Ramesh, N. and Venkateshan S.P. Experimental study of natural convection in a square enclosure using differential interferometer. Int. J. Heat Mass Transfer, 44, 1107, 2001.

33. Velusamy, K., Sundarajan, T. and Seetharamu K.N. Interaction effects between surface radiation and turbulent natural convection in square and rectangular enclosures. Trans. ASME, 123, 1062, 2001.

34. Li, N. and Li Z.X. Relative importance of natural convection and surface radiation in a square enclosure. Int. J. Nonlinear Sci. Numerical Simulat., 3, 613, 2002.

35. Laguerre, O. and Flick D. Heat transfer by natural convection in domestic refrigerators. J. Food Eng., 62, 79, 2004.

36. Nield, D.A. and Bejan, A. Convection in Porous Media. Springer-Verlag Inc., New York, 1992.

37. Cheng, P. Heat transfer in geothermal systems. Adv. Heat Transfer, 14, 1, 1979.

38. Kaviany, M. Principles of Heat Transfer in Porous Media, $2^{\text {nd }}$ Edition. Springer, New Jersey, USA, 1991.

39. Oosthuizen P.H. Natural convective heat transfer in porous media filled enclosures. In: Vafai Kambiz (Ed.), Handbook of Porous Media. Marcel Dekker Inc., New York, USA, 489, 2000.

40. Padet, J. Convection libre. In: Principes des Transferts Convectifs. Ed. Polytechnica, Paris, France, 174, 1997.

41. Rohensenow, W.M., Hartnett, J.P. and Cho I.Y. Handbook of Heat Transfer, Chapter 3 and 4, $3^{\text {rd }}$ Edition. McGraw-Hill Handbooks, Ohio, USA, 1998.

42. Wakao, N. and Kaguei S. Heat and Mass Transfer in Packed Beds. Gordon and Breach Science Publishers, New Jersey, USA, 1982.

43. Ben Amara, S., Laguerre, O. and Flick D. Experimental study of convective heat transfer during cooling with low air velocity in a stack of objects. Int. J. Thermal Sci., 43, 1212, 2004.

44. Raithby, G.D. and Hollands, K.G.T. Natural convection. In: W.M. Rohsenow, J.P. Hartnett, Y. Ohio, USA, Cho (Eds.), Handbook of Heat Transfer. McGraw Hill, Ohio, USA, 1998.

45. Laguerre, O., Ben Amara, S. and Flick D. Experimental study of heat transfer by natural convection in a closed cavity: application in a domestic refrigerator. J. Food Eng., 70, 523, 2005.

46. Laguerre, O. et al. Numerical simulation of air flow and heat transfer in domestic refrigerators. J. Food Eng., 81, 144, 2007.

47. Kingston, P., Woolley, N. and Tridimas, Y. Fluid flow and heat transfer calculations in a domestic refrigerator. FIDAP UK User meeting, Fluent France SA, 1-11, 1994

48. Chui, E. H. and Raithby, G.D. Computation of radiant heat transfer on a non-orthogonal mesh using the finite-volume method. Num. Heat Transfer, Part B, 23, 269, 1993.

49. Colomer, G. et al. Three dimensional numerical simulation of convection and radiation in a differentially heated cavity using the discrete ordinates method. Int. J. Heat Mass Transfer, 47, 257, 2004.

50. Sanchez, A. and Smith T.F. Surface radiation exchange for two dimensional rectangular enclosures using the discrete-ordinates method. J. Heat Transfer, 114, 465, 1992. 